\title{
The Structure of Lobbying And Protection in U.S. Agriculture
}

\author{
KISHORE GAWANDE ${ }^{1}$
}

\begin{abstract}
This paper surveys the empirical literature on the political economy of agricultural protection. A detailed data set of agricultural PAC (Political Action Committee) contributions over five U.S. congressional election cycles over the 1991-2000 period is used to investigate the relationship between lobbying spending and agricultural protection. A detailed graphical analysis of campaign contributions by the agricultural PACs indicates that although there are very many PACs, in most sectors the majority of contributions are made by very few PACs. Econometric analysis reveals that lobbying spending by agricultural PACs is positively associated with the use of nontariff barriers and specific tariffs by the US; there is a strong association between the average US tariff on goods that benefit from US export subsidies and lobbying spending; and no association between agricultural protection and trade measures such as import penetration and the export-to-output ratio.
\end{abstract}

JEL Code: F13, Q18, D72.

Keywords: Lobbying; PACs; Political Economy; Agricultural Protection.

World Bank Policy Research Working Paper 3722, September 2005

The Policy Research Working Paper Series disseminates the findings of work in progress to encourage the exchange of ideas about development issues. An objective of the series is to get the findings out quickly, even if the presentations are less than fully polished. The papers carry the names of the authors and should be cited accordingly. The findings, interpretations, and conclusions expressed in this paper are entirely those of the authors. They do not necessarily represent the view of the World Bank, its Executive Directors, or the countries they represent. Policy Research Working Papers are available online at http://econ.worldbank.org.

\footnotetext{
${ }^{1}$ Helen and Roy Ryu Professor of International Affairs, Bush School of Government, Texas A\&M University. Email: kgawande@tamu.edu. Phone: (979) 458-8034.

Funding from the World Bank is acknowledged.
} 


\section{Introduction}

While many empirical studies, surveyed subsequently in this paper, have investigated and affirmed the role played by lobbies in influencing farm policy, especially in the United States, few have examined the structure of lobbying at a level of detail sufficient to reveal patterns about who lobbies, who are lobbied, and whether lobbies accomplish their goal of influencing policy. The objective of the paper is to fill this shortcoming in the literature.

As we will see, the term lobby takes on different meanings depending on the theoretical context. Thus, informational lobbying means just that - providing information rather than money, while quid pro quo lobbying implies an exchange of money for services in the form of favorable policy. The paper also presents direct and indirect evidence on whether agricultural lobbying in the US is better characterized as informational or quid pro quo lobbying.

Multilateral negotiations that seek to implement freer trade in agriculture must recognize the political-economic nexus that has led to continuous subsidization and protection of agriculture in developed countries, for example in the U.S. since the 1930s. To the extent that lobbies significantly influence agricultural policy, implementing freer trade in agriculture requires designing incentive schemes that take into account the status quo political-economic equilibrium. Accomplishing free trade in agriculture requires effective bargaining at the level of diplomacy. Effective bargaining at that level must be performed over policy options that are politically viable domestically, since governments must serve their constituencies first. And governments do listen to their politically active constituents disparately more than others.

Despite the fact that agriculture accounted for less than 5\% of GDP and employment in developed countries, the farm trade dispute held up the Uruguay Round of negotiations. Agricultural protection was virtually ignored in the first four rounds, by design due to the sector's political sensitivity. Even regional trade agreements routinely exclude agricultural products, without which the agreement might not succeed. The task of multilaterally negotiating reductions in agricultural protection in the Doha round is therefore a challenging one. The extent of trade liberalization in agriculture is already being used as a barometer for the Round's success. To this end, with the objective of designing implementable agreements in mind, this paper investigates lobbying and its role in influencing the structure of agricultural protection in the U.S. 
The paper proceeds as follows. In Section 2 three theoretical classes of political economy models that have gained currency in the literature are described in detail. Evidence about their validity accompanies their description. This existing empirical literature on the political economy of agricultural protection also provides a flavor for the econometric models and data used in this literature. Section 3 graphically analyzes detailed data on lobbying spending by agricultural PACs during 1991-2000. In Section 4 an econometric model is estimated in order to explore the relationship between lobbying spending and agricultural protection. Section 5 summarizes and concludes.

\section{Political Economy Models: A Literature Survey of Theory and Evidence}

De Gorter and Swinnen (2002) provide a comprehensive survey of the theoretical and empirical literature on the political economy of agricultural policies in the developed world. The main body of their survey focuses on three approaches: the Becker-Olson-Stigler model of collective action by lobbies (Becker, 1983, Olson, 1965, and Stigler, 1971); politician-voter interaction models in the tradition of Downs (1957); and the Stigler-Peltzman approach that places different weights on different members of society in the government's objective function (termed the "revealed preference" approach by de Gorter and Swinnen).

This paper's motivation is the same as de Gorter and Swinnen's. They state this aptly (p 1903): "Understanding why governments do as they do allows one to analyze the policy formation process and alter incentive constraints through institutional reform in order to achieve desired policy outcomes" (italics mine). While their survey has gone into depth about the agricultural economics literature on political economy, they do not take into account important and relevant developments outside the agricultural economics literature. The aim of this paper is to complement the de Gorter and Swinnen survey with an analytic survey of recent models about pressure groups that has begun to receive attention in the literature. Of specific interest is the debate over two schools of thought about how those pressure groups operate. One set of models emphasizes that pressure groups lobby by paying for services, while the other set of models maintains that pressure groups seek to informationally lobby policymakers, and money primarily buys access but not the policy itself. It is hoped that the analysis in this paper informs that debate in the context of agricultural policy. We begin with 
an analytic survey of three types of models, all of the special interest or pressure group variety.

\section{A. Olson-Peltzman-Stigler Interest Groups}

Anderson (1992) sets out a unified framework to explain two stylized facts about agricultural protection: (i) special interests matter, and (ii) both developed and developing countries protect their agriculture, but trade barriers are far higher in developed countries. Anderson's political economy model, built on the foundations of Olson (1965), Stigler (1971), and Peltzman (1976), supposes that the government supplies (positive or negative) price support policies $^{2}$ for the sector in response to demand for such assistance by vested interests, mainly farmers. Figure 1 depicts this partial equilibrium model. The price in this political market is political support for the government in the form of lobbying contributions to electoral campaigns (other forms of political support could be used as well). The negatively sloped demand curve (e.g. $\mathrm{D}_{\mathrm{dc}}$ ) represents the marginal willingness of farmers to pay (WTP) for increased assistance. The WTP declines as the amount of assistance increases because more assistance encourages entry of new firms, spreads the benefits over more firms, and worsens the free-rider problem of collective lobbying action by the group. The positively sloped supply curve (e.g. $\mathrm{S}_{\mathrm{dc}}$ ) represents the marginal political cost to the government of providing assistance. This cost increases with the amount of support as greater intervention causes greater welfare losses, thus weakening electoral support from adversely affected consumers.

The quantity of assistance is measured as the effective protection coefficient (the EPC is the percentage by which policy has raised value-added) for agriculture relative to the average EPC for other sectors of the economy. In Figure 1 equilibrium in developed countries (dc) occurs at a quantity greater than one, indicating that agriculture receives more protection on average than other sectors. Equilibrium in developing countries occurs at a quantity less than one, indicating that agriculture is discouraged relative to other sectors.

\footnotetext{
${ }^{2}$ The quantity of assistance may be measured variously by the nominal protection coefficient (NPC) which measures the difference between world and domestic prices as a result of the price support, the effective protection coefficient (EPC) which measures the amount by which the policy raises value added, or producer/ consumer subsidy equivalent (PSE, CSE) which measures the monetary benefit to producers/consumers as a result of the policy as a percentage of production value in the absence of the subsidy.
} 
This policy disparity between developed and developing countries has been well documented in the literature. According to Anderson this disparity is due do dissimilar distributional effects of policy intervention in these two types of economies, as well as differences in the relative costs of collective action by interest groups. If capital, including land, is sector-specific and labor is mobile, the distributional effects of a policy that alters farm prices is determined by (i) its impact on wage costs and (ii) the share of the expenditure on food. In a poor agrarian economy raising the relative price of agricultural products can substantially raise wage rates by increasing labor demand in the labor-intensive agricultural sector. This substantially lowers the income of owners of land and industrial capital.

Together with the high costs of lobbying organization (farms are small and farmers numerous, making the free rider problem insurmountable) this makes for weak demand for farm price support policies relative to demand for policies that support the industrial sector. The demand and supply curves in political markets in developing countries therefore intersect towards the lower left in Figure 1.

In rich industrial economies, farmers are a small proportion of the labor force. Raising the relative price of farm products has little impact on the demand for labor and consequently wages. Counter lobbying by consumers is thus not an issue. Further, since people spend a small part of their income on farm products they are less sensitive to an increase in farm price. As a result, the supply curve in industrial economies is far to the right of that in developing countries in Figure 1. The demand curve lies to the right as well. Farms are large, and the stakes from price support policies are high. Institutionally commercialization of agriculture has given rise to cooperatives, which has also reduced the free-rider problem of political organization in this sector.

A simulation exercise by Anderson (1994) suggests that an increase in the relative price of farm products would raise farm owner-operators' real incomes in the typical poor country by only one-tenth as much as it would reduce the real incomes of industrial capitalists, while a similar price policy shock in the typical rich country raises farmers' real incomes substantially more than it reduces the incomes of industrial capitalists. 


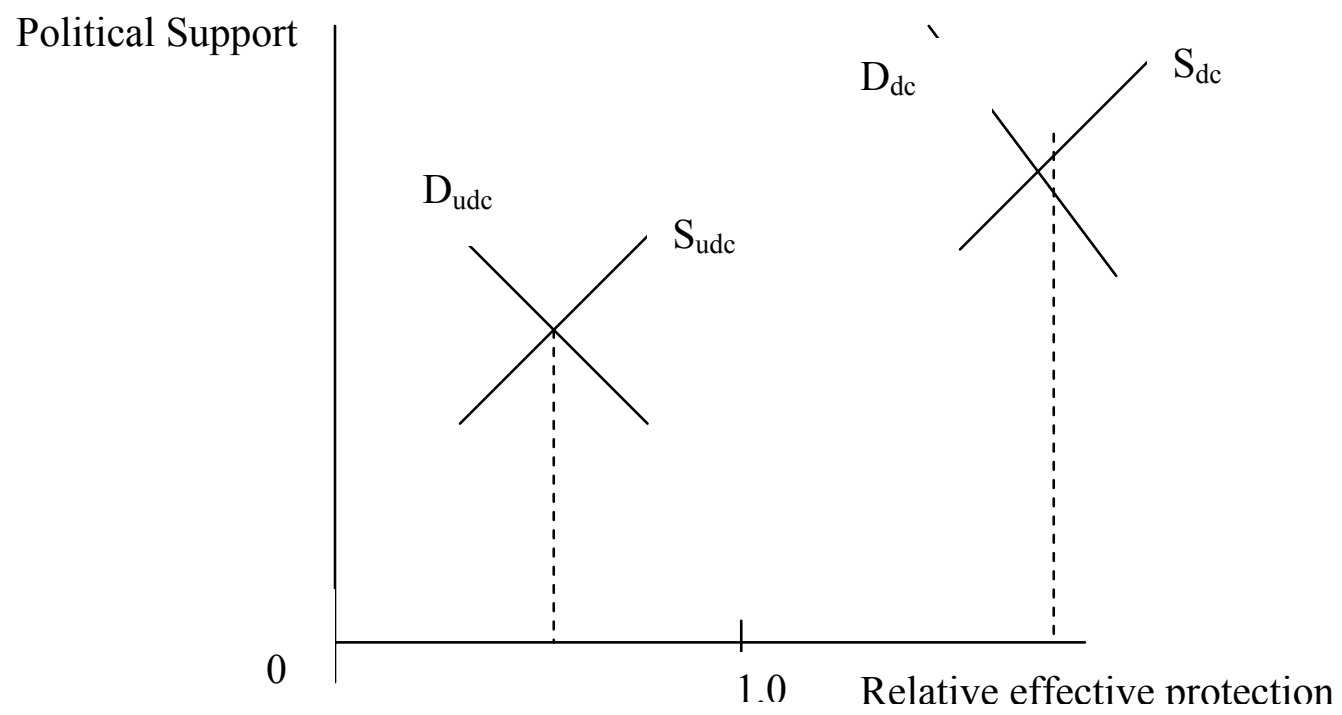

\section{Figure 1: The political market for government assistance to agriculture}

Moreover, the real incomes of non-farm workers would be lowered by four times as much in the poor as in the rich country. They would be more inclined to join industrialists in opposing price support policies in a poor than in a rich country. Even poor countries with a wealthy landed aristocracy are likely to adopt policies that discriminate against agriculture, since landowners typically are also to some extent industrial capitalists. Anderson's simulation exercise suggests that if landlords earned as little as one-sixth of their income from industrial capital they would prefer policies which lowered the domestic price of farm relative to industrial products. This helps explain why Krueger (1990b) found agriculture to be only slightly less discriminated against in those developing countries with concentrated land ownership as compared with those with a more even distribution of land.

Other authors have put forth various extensions of the pressure group model to explain agricultural price policy. Swinnen and de Gorter (1994) and Swinnen (1994) develop politician voter models, building on a combination of Stigler (1971), Downs (1957), and de Gorter and Tsur (1991). Their main conclusion can be summarized in five testable propositions put forth in Swinnen (1994) (and tested in Olper, 1998, see below): (i) politicians increase agricultural subsidies as real agricultural income falls, (ii) the equilibrium subsidy increases as a share of agriculture in total output decreases, (iii) the equilibrium subsidy increases as capital intensity increases (inside and outside agriculture), (iv) the equilibrium 
subsidy increases as supply elasticity increases, and (v) demand elasticities influence the subsidy for large importers and exporters.

Empirical evidence about agricultural protection using the framework of Anderson (1992), Anderson and Hayami (1986), and Swinnen (1994) is plentiful. Two studies that employ cross-country agricultural protection data are summarized here, leaving discussion of U.S. studies for the following section. Olper (1998) employs a reduced form econometric model to explain the structure of Common Agricultural Policy (CAP) transfers in eight countries in the European Union. He considers effective and nominal protection rates in these eight countries annually over 1975-1989. The explanatory variables are (loosely) motivated by (i) the pressure group model of Becker $(1983,1985)$ and Olson (1965), (ii) extensions of the model of voter-politician interactions by de Gorter and Tsur (1991) and Swinnen (1994) and de Gorter and Swinnen (1994), and (iii) the model of altruism by Bullock (1994). Olper's panel regression estimates yield three findings. First, agricultural protection increases under adverse market conditions for the farming industry supporting the counter-cyclical hypotheses of Bullock. Second, countries with comparative disadvantage in agriculture enjoy greater protection in agriculture supporting the view that Stolper-Samuelson effects motivate losers from liberalization to organize politically. Third, a high budget share for food consumption reduces protection perhaps indicating government's concern for welfare losses from protection. In sum, both, special interests as well as government concern for welfare determine the structure of CAP transfers.

Honma (1993) empirically investigates whether Japan's agricultural protection is determined according to the Anderson-Hayami (1986) framework of endogenous protection. The dependent variable in his regression is a nominal protection coefficient (NPC) measured as the ratio of the value of agricultural output in domestic prices to its value in border prices. Its log represents a rate of difference between the output valued in domestic and border prices. Using panel data on 14 industrial countries between 1955-1987 Honma finds that (i) NPC declines with comparative advantage in agriculture (measured as the ratio of labor productivity in agriculture to labor productivity in industry), (ii) there is inverted-U shaped relationship between the NPC and the share of agriculture in output (or employment), with a threshold value of that share equal to $4.5 \%$; that is, NPC rises as the share in agriculture increases to $4.5 \%$ and falls beyond that, (iii) NPC increases as the terms of trade (measured as 
ratio of the index of world export unit value of agricultural products to the export unit value index of manufactured goods), decline in agriculture, and (iv) region specific dummies indicate that European Union and other non-aligned European countries had a far higher growth in NPC than either Japan, the Asian new industrializing economies, or the U.S. Honma concludes that as economies reach advanced stages of development the political environment favors protection in the agricultural sector for two reasons. First, the relative contraction of agriculture in the total economy reduces the consumers' resistance to agricultural protection. Second, the contraction of agriculture leads to greater concentration and therefore makes political lobbying by farmers more efficient. On Japanese protection, Honma concludes that while the pre-1975 growth in the NPC was largely due to changes in comparative advantage, after 1975 the main determinant was the declining terms of trade against Japanese agriculture.

While the ideas present in the next two classes of models have existed informally in the literature over many years, only recently have they been modeled using well defined objective functions and solved formally in order to investigate the properties of the equilibrium solutions. The first class of models takes the position that both lobbyists and decision-makers in policy view lobbying as essentially providing information. Money plays the secondary, though important, role of buying access to policymaker. This theory of lobbying, originally developed in Bauer, Pool and Dexter (1963) and Milbraith (1960), has received formal treatment in Ainsworth and Sened (1993), Austen-Smith (1995, 1995), Bennedsen and Feldman (2002) and Wright (1990). Hansen (1991) finds the theory of informational lobbying relevant and applicable to U.S. agricultural policy over this century. The second class of models considers lobbying as a means of buying favorable policy, not merely access. This view is most effectively put forth in Grossman and Helpman (1994).

\section{B. Informational Lobbying}

Ainsworth and Sened (1993) offer a sophisticated non-exchange based rationale for the emergence of lobbies. Their thinking is that lobbies endogenously emerge whenever there is uncertainty on the part of politicians about the true demand for the public goods which they have the power to provide. Thus the focus is on the informational role that lobbies provide. Lobbies endogenously form since their existence improves the efficiency of the interaction 
between government and particular interests, by providing information more economically than it would pay government to obtain the same information by itself. Of course, lobbies are not able to provide exact information about the true demand, only signals. But these signals enable the elimination of inefficient equilibria. Essentially, lobbies are able to create surplus due to such informational efficiencies, which politicians and lobbies share and are left better off. Perhaps, this model is appropriate for explaining the boom in the number of lobbies that are issue-based such as green lobbies. The theory is difficult to test since it offers few clues about what the "reduced-form" function for (some measure of) lobbying might look like.

A case is strongly made for the relevance of informational lobbying in Hansen's (1991) study of the politics of U.S. agricultural support policies. His informal, yet intuitive, theory is based on his observations about the interactions between Congress and the farm lobby over the period 1919-1981. The theory is designed to explain three stylized facts about how the farm lobby gained and lost access to Congress over this period.

- In the 1950s and 1960s, farm policy makers dropped the American Farm Bureau Federation (AFBF) from its dominant position in agricultural politics. AFBF had been agriculture's leviathan for a generation. In the 1960s and the 1970 s commodity organizations replaced the position previously occupied by the AFBF.

- In the 1960s and the 1970s farm policy makers paid less and less attention to the advice of farm lobbies.

- In the 1970 s and 1980 s, this was reversed, and they scarcely paid attention to the advice of consumer lobby.

In sum, during those 40 years, Congress reallocated access within the farm lobby, Congress restricted access for the farm lobby but Congress denied access to the consumer lobby. Hansen develops a theory to explain these changes in access. His theory is developed around (i) competitive advantage in a lobby's ability to deliver better information to politicians than their rival groups, and (ii) recurrence of issues around which a lobby makes its case to the politicians. Hence, politicians grant access to lobbies on the basis of their informational advantage over other lobbies, and also the permanence of the issues and positions conveyed by the lobbies. Hansen's theory of access is based not so much on the direct monetary contributions by lobbies as on their informational contributions. In his view, 
money does not cause votes, information does. Hansen finds his theory provides satisfactory explanations of the three observations made above.

Austen-Smith (1993) focuses on lobbying committee members in order to influence their votes as well as shape the committee's agenda. In this model lobbying is the mechanism for transmitting strategic information from interest groups to committee members. AustenSmith finds support for his theory in Hansen's finding that there was widespread transmission of information from the farm lobby to the agricultural committee, in spite of (or perhaps because of) the fact that lobbyist preferences over issues like price supports were opposed to those of the House as a whole.

Austen-Smith (1995) develops a model of access via campaign contributions, where the role of lobbying is primarily to reveal to the policymaker the policy preferences of the lobbyist. To put this model in the context of agricultural policy, consider a hypothetical example. While it is common knowledge that agriculture will be scrutinized in the coming legislative session it is not clear exactly whether issues such as price supports will consume the agenda. Thus lobbyists pay to purchase the option to speak to the legislator should such an opportunity arise. In this model money exchanges hands before details of the legislative agenda are revealed. The sequence of steps in this game are as follows. First, the group chooses its contribution; next, it is probabilistically determined whether the issue is relevant to the group; next, if the issue is relevant (else the game ends), then the legislator chooses whether to grant access; next, if access is granted the group makes it's lobbying speech and the legislator makes a decision (otherwise the legislator makes a decision without granting access) and the payoff is distributed. Austen-Smith's model is able to theoretically explain the strong positive correlation between lobbying contributions and the preference similarity between the lobby and the legislators that these lobbies woo (or negative correlation between contributions and preference disparity).

Kollman (1997) finds such a positive empirical correlation. More precisely, he finds a strong correlation between the preference biases of lobbyists and committee members who they lobby. On the issue of whether this is a causal relationship (as postulated by AustenSmith) or a correlation due to common preference biases of legislators and lobbyists that brings them together, Kollman opts for the latter. 
Bennedsen and Feldman (2002) extend these models of informational lobbying with a single decision maker, to address the fact that ultimately the purpose of lobbying is to influence legislation, which is made by Congress. Hence, any complete theory of informational lobbying must take into account the process by which majorities are formed during legislation of policy. They develop a theory whose main conclusion is that the ability to create majorities in Congress provides the necessary incentives to lobby groups to carry out their activities.

The findings in Wright (1990) empirically motivate the relevance of the BennedsenFeldman model. Wright conducted a survey of lobbies that had contacted Ways and Means committee members and Agriculture committee members of the U.S. House of Representatives. His inference that money contributions plus informational lobbying influenced voting in Ways and Means affirms the first view that informational lobbying does matter. Further, Wright found that lobbying mattered more than money to Ways and Means committee members (that is, money bought access in order to informationally lobby). Wright's findings about lobbying of Ways and Means member have two implications: (i) taking note of the fact that decisions are made not individually but in committees of the Congress, rather than target one individual lobbyists allocate their scarce resources over a set of influential decision makers, and (ii) lobbying is informational. The Bennedsen-Feldman contribution is thus more relevant than previous theoretical models that presumed informational lobbying of an individual decision maker.

Notably, Wright finds very weak evidence of informational lobbying of the House Agriculture committee, the most influential policymaking committee in agriculture. The specific content of the five-yearly Farm bills are determined in this committee. In Wright's data strong collinearity among regressors precluded reliable inferences about informational lobbying of the Agriculture committee. Wright attributes the weak finding to the fact that the Agriculture committee deals with a narrow and well defined set of issues on a periodic basis (as different from Ways and Means which attacks a range of diverse issues, often on an ad hoc basis). Both, leaders and rank and file members of the Agriculture committee, have ample opportunity to regularly interact with lobbies. The preferences of these lobbies have been fairly constant over time, and so those preferences are well known to Agriculture committee members (as different from Ways and Means whose members encounter a variety of 
lobbyists, often on an issue-by-issue basis, so that informational lobbying by those lobbies is influential on the margin). Hence, informational lobbying of Agriculture committee members is not influential on the margin in the formation of coalitions.

This view of Agriculture committee members possessing a strong continuing link with PACs, whose preferences have been stable over time, is endorsed in Parker and Parker (1998). They factor-analyze data on voting within committees, where leadership is less partisan and more attuned to the issues and lobbying interests surrounding those issues, versus voting on related issues after those issues have left the committee for the floor, where floor leaders are more partisan and seek to establish coalitions based on party and ideology. Parker and Parker's aim is to differentiate committees in the House in which voting by their members do not change as issues move from committee to the floor from committees in which voting does change. Agriculture and Ways and Means are the two highest ranked in terms of the stability of coalitions as their issues move from committee to the floor. ${ }^{3}$ Parker and Parker take this to imply that the influence of special interests on forming preferences of committee members on these committees is strong. In other committees, members often change their votes on the floor, indicating that their preferences while serving on committees were weak to begin with.

In sum, evidence on the relevance and effectiveness of informational lobbying, at least in the context of agricultural policy, is an open issue and deserves further investigation. Hansen finds for informational lobbying, while Parker and Parker do not. Hansen's is a longterm exercise and identifies threshold points in time during which legislators sought better information because they recognized it to be marginally effective in increasing electoral strength. Shorter run studies do not find this to be the case.

\section{Quid Pro Quo Lobbying}

In contrast to Hansen (1991), Grossman and Helpman (1994) put forth a theory of how policy responds to lobbying contributions. In their model, money causes votes and is the source of electoral strength. A stylized fact that supports this view is that lobbying contributions account for a significant share, up to $80 \%$, of a congress person's total campaign

\footnotetext{
${ }^{3}$ This finding about Ways and Means is at odds with Wright's findings from his survey of lobbies.
} 
expenditures. $^{4}$ With soft money playing a bigger role in recent years, this proportion has increased on average. Among the models of special interest that have been advanced in political economy, the GH model yields the sharpest testable conclusions.

The Grossman-Helpman model is a small open economy model. A numeraire good is produced using only labor, which fixes wage. $n$ goods are produced using CRS technology with labor and sector-specific capital. Trade policy is quantified in the domestic price vector p. An import tariff or export subsidy on good $i$ raises $p_{i}$ above the world market price $\pi_{i}$. Conversely, an import subsidy or export tax on good $i$ lowers $p_{i}$ below the world market price $\pi_{i}$. Net government revenues are redistributed on a lump-sum basis. Individuals in the economy differ only in their ownership of sector-specific factors. Each individual owns specific capital in at most one sector, and the total supply of specific capital in any sector is inelastic. Hence, the reward to sector-specific input in good $i$ is increasing in $p_{i}$.

Government maximizes a weighted sum of welfare and lobbying contributions (free trade would be the efficient outcome if government maximized only welfare). Capital owners in some sectors $L$ organize into interest groups in order to attempt to influence government's policy. Through lobbying contributions, the lobby representing sector $i$ aims to increase $p_{i}$, and/or decrease prices of other goods (since individual lobby members consume other goods, decreasing their price raises welfare of lobby members). ${ }^{5}$ Lobby $i$ offers government contingent campaign contributions $C_{i}(\mathbf{p})$, conditional on the trade policy $\mathbf{p}$ that the government chooses. Grossman and Helpman model the lobbying game as a menu auction. After the lobbies submit their contingent contribution schedules, the government sets trade policy p. In a pure menu auction, every lobby makes a menu of offers to the government (the menu may, and probably will, comprise zero contributions corresponding to subsets of the policy space), and government auctions policy to highest bidder. A pure menu auction would be the case if the government were interested purely in contributions and not on welfare. In the Grossman-Helpman model government maximizes a weighted sum of campaign contributions $C$ and gross welfare $W$ :

\footnotetext{
${ }^{4}$ My own observation after perusing a number of congressional profiles between 1980 and 2000 comprehensively summarized by Congressional Quarterly in their "Politics in America" volumes.

${ }^{5}$ Either that is the case or the output of other industries is used as intermediate inputs by industry $i$, or both.
} 


$$
G=a W+C
$$

Thus, the Grossman-Helpman model is more than a pure menu auction model, and is better described as a common agency model where lobbies are the principals and government is the common agent. The common agency problem has been formulated and solved by Bernheim and Whinston (1986).

On the lobbying side, Grossman and Helpman posit that equilibrium lobbying contribution schedules (i.e. the menus they offer the government) are the result of lobbying competition, and determined in a Nash equilibrium. In deciding their menus, every lobby takes into consideration the maximization of (1) by the government. Take the example of an economy with just one lobby, say, in sector 1 . With negligible membership relative to the population lobby 1 is interested purely in $p_{1}$ and would like the government to set it above the world price $\pi_{1}$. The lobby submits a menu of offers given by its contribution schedule $\mathrm{C}_{1}\left(p_{1}\right)$, which is in turn determined by the maximization of the sum of the individual members' welfare functions, $\Sigma_{i \in L} W_{i}\left(p_{i}\right){ }^{6}$ The government can choose either to set $p_{1}$ at a level above the world price, and collect the contribution associated with that level, or ignore the lobby and collect zero contribution. Let $G^{*}$ denote the value of the political welfare function if $p_{1}=\pi_{1}$. In order to obtain a more favorable policy, lobby 1 must ensure the government a political welfare of at least $G^{*}$. That is, it must compensate the government to the extent of the welfare loss from protecting sector 1. But the lobby gets to keep any and all surplus (the aggregate change in the welfare of each member net of contributions). When there is more than one lobby, there is lobbying competition and lobbies may have to contribute beyond the welfare loss to the government.

On the protection side, the model predicts that the cross-sector pattern of protection is given by

$$
\frac{t_{i}}{1+t_{i}}=\left(\frac{-\alpha}{a+\alpha}\right) \times \frac{Z_{i}}{e_{i}}+\left(\frac{1}{a+\alpha}\right) \times\left(I_{i} \times \frac{Z_{i}}{e_{i}}\right),
$$

\footnotetext{
${ }^{6}$ The individual welfare functions comprise three components: producer profits, consumer surplus, and tariff revenue. Since individuals maximize quasi-linear utility functions with desirable properties, the expression for consumer surplus is simple. See Grossman and Helpman (1994) eq. (4).
} 
where $t_{i}=\left(p_{i}-\pi_{i}\right) / p_{i}$ is the ad valorem tariff or export subsidy for good $i$ in equilibrium, $I_{i}$ is an indicator variable that equals one if sector $i$ is organized into a lobby. The parameter $\alpha \leq 1$ is the fraction of the population organized into lobbies. $a>0$ is the government preference parameter in (1), and indicates the weight government places on a dollar of welfare relative to a dollar of political contributions. $z_{i}=x_{i} / m_{i}$ is the equilibrium ratio of domestic output to imports and $e_{i}$ is the absolute elasticity of import demand. ${ }^{7}$ If sector $i$ is a net importer then it is protected $\left(t_{i}>0\right)$ or obtains an import subsidy $\left(t_{i}<0\right)$ depending on whether it is organized $\left(I_{i}>0\right)$ or not $\left(I_{i}<0\right)$.

(2) may be interpreted as follows. The second component on the right hand side of (2) indicates that protection to organized sectors is given according to their z/e ratios. Since deadweight loss from protection is higher in industries with high import elasticities the government is averse to protecting these industries, all else equal. $z$ measures the stakes from protection, and industries with high $z$ values will make larger lobbying contributions. The lower the import volume, the lower the social cost imposed on individuals, thus diluting their opposition to protection of that sector. The first component on the right hand side of (2) indicates that negative protection to unorganized industries is given according to their $z / e$ ratios. $\alpha$ measures the extent of opposition to protection. If only a negligible fraction were organized into lobbies, $\alpha=0$, then there would be no organized opposition to protecting any sector (only organized support for protecting a lobby's own sector). If everyone were organized, $\alpha=1$, then organized lobbying for protection in any sector would be balanced out by organized opposition to that protection, and tariffs would be zero.

Goldberg and Maggi (1999) and Gawande and Bandyopadhyay (2000) have empirically investigated these predictions using U.S. manufacturing industry data, Mitra, Thomakos and Ulubasolglu (2002) with Turkish data and McCalman (2002) with Australian data. They affirm the predictions qualitatively. Gawande and Bandyopadhyay also examine the lobbying side of the Grossman-Helpman model. They affirm the fundamental prediction

\footnotetext{
${ }^{7}$ The Ramsey pricing logic applies here. The Ramsey tax formula implies that if the demand for a good is uniformly less elastic than that for another good, the optimal tax rate is higher for the first good due to the lower deadweight loss from taxing it rather than the second good. If the first good is totally inelastic there is no deadweight loss from taxing it, and the first best can be reached by taxing just this good.
} 
that contributions increase with deadweight loss from protection. Further, lobbying spending rises with the share of an industry's output that is used by politically organized downstream industries.

Gardner's (1987) work on explaining agricultural protection pre-dates the GrossmanHelpman model but is prescient about the key features of the Grossman-Helpman model. In Gardner's model government maximizes the weighted sum of buyer's surplus (B) and producer's rents $(\mathrm{R})$ which are functions of farm output quantities, $W=B+\theta R$. Efficient redistribution using production controls in this framework ${ }^{8}$ requires choosing quantities of farm products to maximize W. Unlike Grossman and Helpman, who adopt a formal model of the lobbying process and, as a result, are able to provide micro-foundations for their objective function, Gardner does not provide micro-foundations for W. However, he uses Peltzman's (1976) "majority generating function" as the argument for using this type of objective function. He attributes the same forces that determine lobbying effectiveness as determining the value of the parameter $\theta$. Specifically, Gardner measures these forces for seventeen farm commodity by the number of producers, their geographical dispersion, the stakes from redistribution (output per farm), and the stability of the industry (variability of production patterns). He also estimates (long-run) demand and supply elasticities for those commodities.

Pooling data across the seventeen commodities over the period 1912-1980 yields a sample of 1124 observations for Gardner's empirical analysis. The dependent variables measuring intervention differ across different commodities, but are variants of the nominal protection coefficient. Gardner finds that the lower (greater) the (inverse) demand elasticity, the greater the level of intervention, that is, the higher the price relative to it's non-distorted price. This is a confirmation of the Grossman-Helpman intuition that it is most efficient to tax commodities with the lowest price elasticities of demand, and is the basis for Gardner's conclusion that interventions in U.S. agriculture have been efficient.

From the coefficients of other explanatory variables, Gardner finds strong support for the political economy model view of price supports in U.S. He finds: an inverse-U relationship between the number of producers and producer protection; that geographical concentration leads to greater protection; prolonged concentration of production in a few

\footnotetext{
${ }^{8}$ Deadweight loss, as in the Grossman-Helpman model, has no normative implications given the objective function, and represents the real resource cost of redistributive services.
} 
states increases protection; protection decreases in farm income and as prices improve; imported commodities receive greater price supports; the greater the share of output exported, the greater the amount of price support. All these coefficients support some political economy model, though the precise connection is not made formally clear and the connection of the variables to any underlying theory is tenuous. Regardless, the collective evidence in favor of the influence of special interest is impressive. ${ }^{9}$

The next two sections contain the empirical contribution of this paper. Data on the structure of lobbying by agricultural political action committees (PACs) is merged with data on agricultural protection in order investigate evidence of direct association between the two. The models discussed above all indicate that lobbying matters, whether lobbying involves money in exchange for favorable policy or whether it involves provision of information that is mutually beneficial to the lobbyist and policymaker. The detailed graphical analysis of the structure of lobbying spending undertaken in the next section does inform the debate about whether lobbying in the US agricultural sector is informational or of a quid-pro-quo nature. The formal econometric analysis that follows, however, does not distinguish between the two types of lobbying. Rather, it is motivated by the need to make the association between lobbying and protection explicit.

\section{Graphical Analysis of PAC Contributions 1991-2000}

A. Data

Raw lobbying data for the five congressional election cycles (for the $103^{\text {rd }}$ through $106^{\text {th }}$ Congress) between 1991-2000 were downloaded from the Federal Election Commission (FEC) website (www.fec.org). The data are in three relational data files: candidate information files $(\mathrm{CN})$, PAC committee information files $(\mathrm{CM})$, and files containing transactions between PACs and candidates (PAS). For each election cycle, aggregate contributions by each PAC to every candidate were computed from the PAS files, and then

\footnotetext{
9 While the three sets of models described up to this point emphasized varying degrees of pressure by farm interest groups, Paarlberg (1989) believes that they do not provide a complete understanding of U.S. agricultural policy to data. What these theories miss, according to Paarlberg, is the government's concern for poor economic conditions in the sector. Such concerns motivated Roosevelt's introduction of price support programs via the Agricultural Adjustment Act of 1933. Those price supports are integral to U.S. agricultural policy to this day.
} 
merged with the relevant cycle's CN files. The House and Senate files were separated for each cycle. Congressional committee and sub-committee assignments for each Congress were obtained from Congressional Quarterly (1991-1999).

Mapping from PACs to SIC-based agricultural-related sector makes use of the concordance by Beaulieu and Magee (2002). ${ }^{10}$ In general the mapping is many-PACs-tomany-SIC-codes. For many-to-one maps, the contributions were simply aggregated for each SIC code. For one-to-many maps, political contributions from each PAC were fractionally assigned equally to each SIC code into which the PAC mapped. To check the consistency of the PAC data, they were compared with the data on the opensecrets.com website. Our data are very comparable in the aggregate, as well as those sectors for which opensecrets.com does report data.

\section{B. PAC Spending Across Agriculture-Related Sectors}

Figure 2 shows the breakdown of PAC contributions by 2-digit SIC agriculture-related sectors in the 1991-92 election cycle (first bar) and the 1999-2000 cycle (second bar). The striking feature here is that the contributions have held fairly steady over the ten-year period. It appears that the same PACs have contributed fairly predictable amounts of money over this period. Rather than use the 2-digit descriptions, subsequent figures break down farm PACs by seven products - wheat, dairy, sugar, vegetables and fruits, cotton, ranch and other. Figure 3 depicts the total contribution by agriculture-related sectors for each of the five election cycles between 1991 and 2000. In order to compare farm PAC contributions with other agricultural related sectors, Figure 3 also shows contributions by PACs in the following major sectors: Farm Equipment, Agricultural Services, Crop Processing Services, Distribution, Forestry/Nursery, and Food Manufactures.

Farm PACs contributed between $\$ 5.5 \mathrm{mn}$. and $\$ 7 \mathrm{mn}$. during each of those five election cycles. Among farm products the most politically active were sugar PACs, dairy PACs and ranch PACs. Together these three PACS accounted for about $75 \%$ of total farm PAC contributions ${ }^{11}$.

\footnotetext{
${ }^{10}$ I am grateful to Chris Magee for making this available.

${ }^{11}$ By comparison agriculture related non-farm PACs contributed between $\$ 9$ and $\$ 10 \mathrm{mn}$. per cycle during this period. Food manufacturing PACs, Forestry-Nursery PACs, Agriculture Services PACs and Distribution PACs were even more active in absolute terms than Farm PACs.
} 
Figure 2: PAC Spending in 1991.92 and 1999.00 Election Cycles

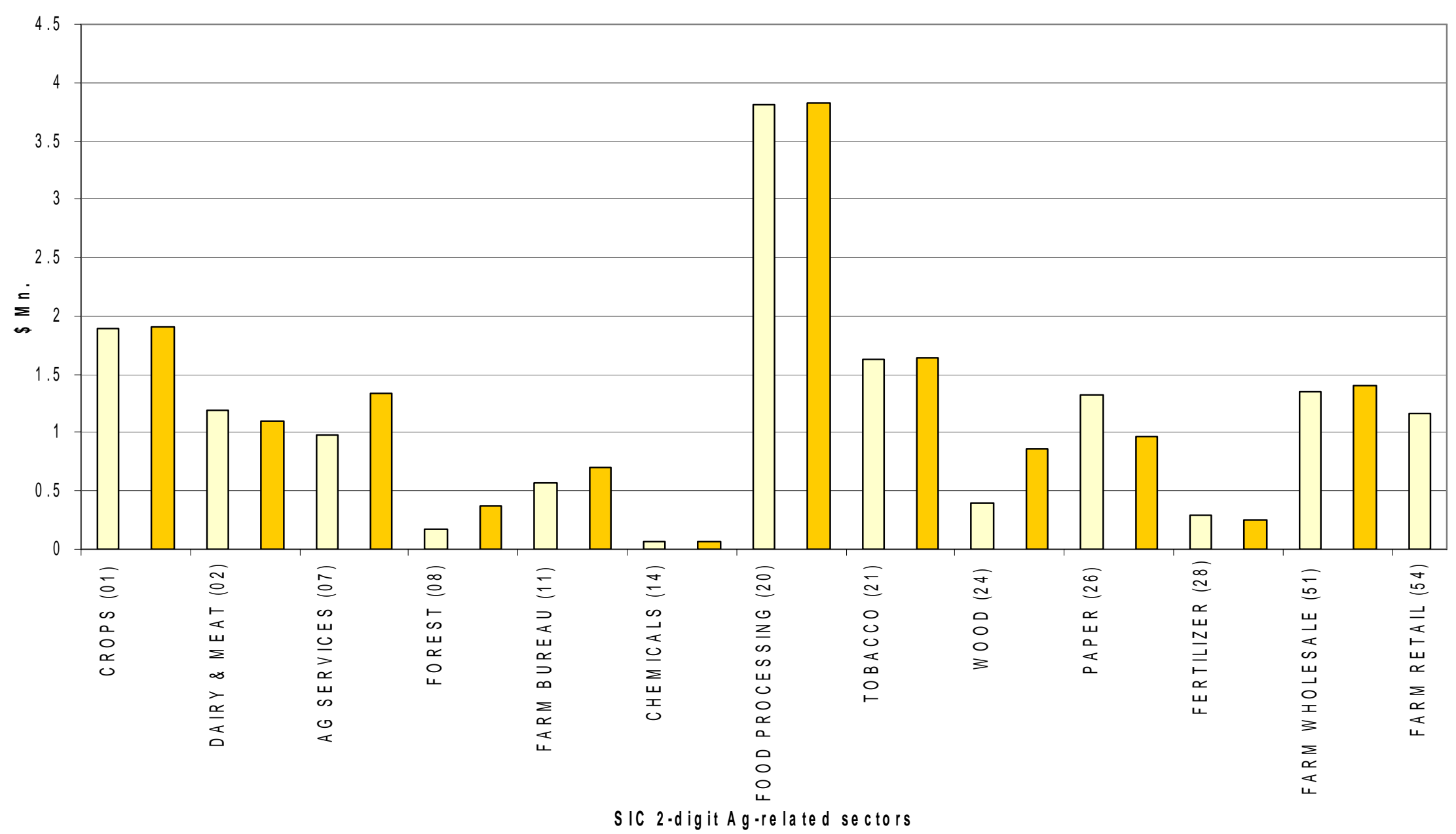


Figure 3: PAC C ontributions Per Election C y cle, 1992.2000. D istribution by Ag-related sector.

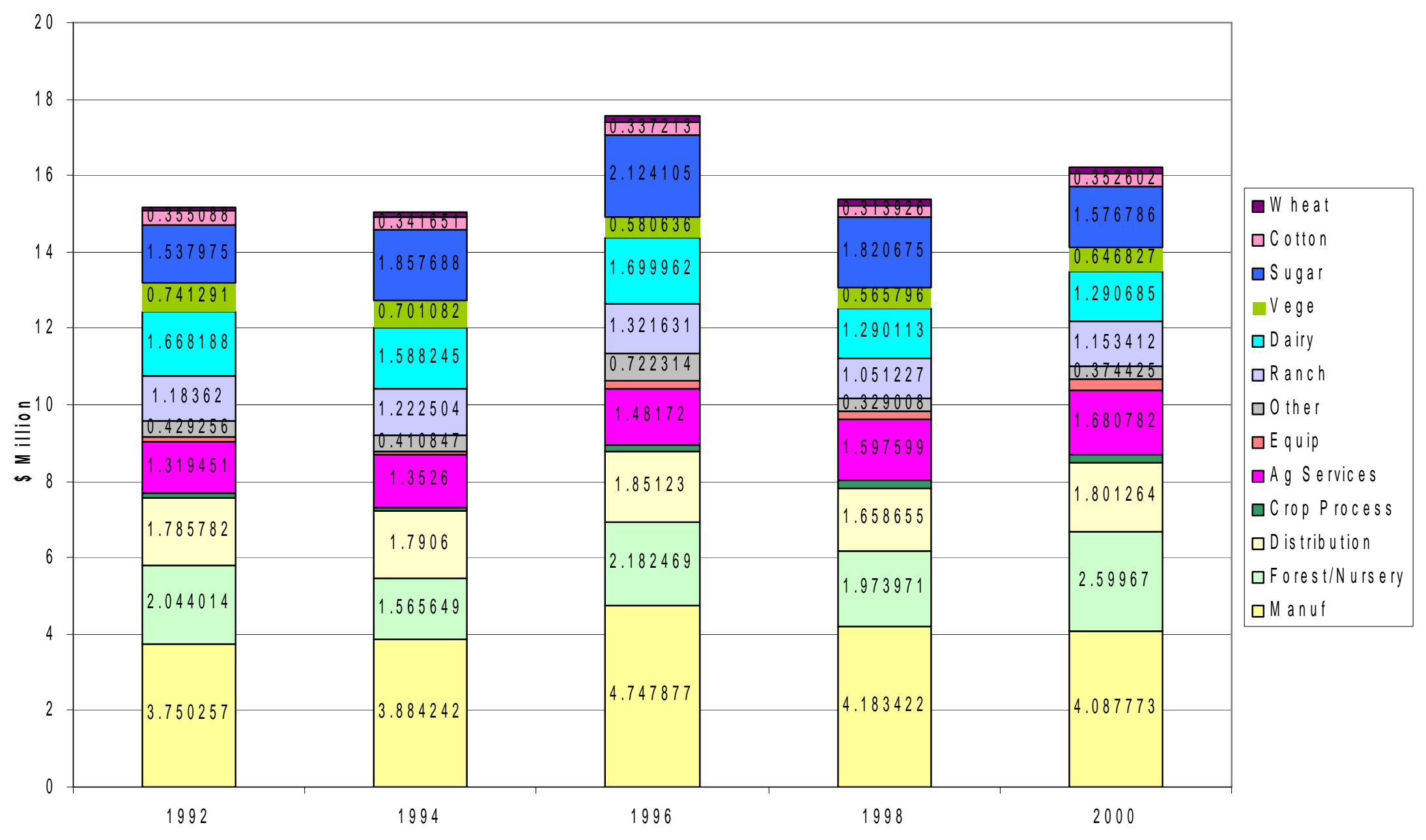


Table1: Herfindahl Index: 1991- 2000

\begin{tabular}{lcccccc}
\hline \hline & $\mathbf{1 9 9 2}$ & $\mathbf{1 9 9 4}$ & $\mathbf{1 9 9 6}$ & $\mathbf{1 9 9 8}$ & $\mathbf{2 0 0 0}$ & Average \\
\hline Wheat & 0.326 & 0.301 & 0.336 & 0.294 & 0.329 & 0.317 \\
Dairy & 0.333 & 0.320 & 0.287 & 0.329 & 0.384 & 0.331 \\
Sugar & 0.127 & 0.164 & 0.134 & 0.140 & 0.121 & 0.137 \\
Vege & 0.099 & 0.084 & 0.076 & 0.084 & 0.065 & 0.082 \\
Cotton & 0.340 & 0.411 & 0.296 & 0.364 & 0.363 & 0.355 \\
Ranch & 0.143 & 0.154 & 0.144 & 0.152 & 0.152 & 0.149 \\
Other & 0.127 & 0.149 & 0.141 & 0.114 & 0.099 & 0.126 \\
Equip & 0.593 & 0.603 & 0.463 & 0.479 & 0.538 & 0.535 \\
Ag Services & 0.121 & 0.113 & 0.104 & 0.130 & 0.143 & 0.122 \\
Crop Processing & 0.986 & 1.000 & 0.976 & 0.893 & 0.901 & 0.951 \\
Distribution & 0.136 & 0.110 & 0.154 & 0.165 & 0.132 & 0.139 \\
Forest/Nursery & 0.077 & 0.059 & 0.060 & 0.075 & 0.073 & 0.069 \\
Manuf & 0.083 & 0.105 & 0.071 & 0.073 & 0.073 & 0.081 \\
\hline & $4-P A C$ & Concentration Ratio & $1991-2000$ & & \\
\hline & $\mathbf{1 9 9 2}$ & $\mathbf{1 9 9 4}$ & $\mathbf{1 9 9 6}$ & $\mathbf{1 9 9 8}$ & $\mathbf{2 0 0 0}$ & Average \\
Wheat & 0.956 & 0.942 & 0.892 & 0.950 & 0.939 & 0.936 \\
Dairy & 0.866 & 0.881 & 0.863 & 0.835 & 0.843 & 0.858 \\
Sugar & 0.646 & 0.676 & 0.655 & 0.652 & 0.620 & 0.650 \\
Vege & 0.527 & 0.512 & 0.469 & 0.495 & 0.401 & 0.481 \\
Cotton & 0.953 & 0.948 & 0.887 & 0.899 & 0.897 & 0.917 \\
Farm & 0.704 & 0.673 & 0.601 & 0.644 & 0.639 & 0.652 \\
Other & 0.611 & 0.597 & 0.676 & 0.569 & 0.503 & 0.591 \\
Equipment & 1.000 & 1.000 & 1.000 & 1.000 & 1.000 & 1.000 \\
Ag Services & 0.608 & 0.573 & 0.523 & 0.590 & 0.610 & 0.581 \\
Crop Processing & 1.000 & 1.000 & 1.000 & 1.000 & 1.000 & 1.000 \\
Distribution & 0.633 & 0.551 & 0.690 & 0.694 & 0.642 & 0.642 \\
Forest/Nursery & 0.464 & 0.371 & 0.377 & 0.437 & 0.445 & 0.419 \\
Manuf & 0.513 & 0.465 & 0.456 & 0.458 & 0.451 & 0.469 \\
\hline & & & & & &
\end{tabular}

How many PACs are active in the agriculture and related sectors? Our database indicates over 200 PACs that were politically active during this period. Table 1 indicates the "market structure" of PACs in the political market place. Among farm PACs, cotton, dairy and wheat had the highest degree of PAC concentration. The four PAC concentration ratio in the lower panel of Table 1 shows that wheat and cotton farms were represented politically almost entirely by four PACs. Even dairy, ranch and sugar had high levels of PAC 
concentration. The inverse of the Herfindahl indices represents the number of equal-sized PACs that are active in each sector. Hence, cotton, dairy and wheat each had the equivalent of three to four equal sized PACs representing them politically. Ranch, sugar, and fruits and vegetables were represented by the equivalent of eight to ten PACs ${ }^{12}$.

One message is that a high degree of concentration among PACs does not translate unconditionally into high PAC spending. For example, wheat PACs are highly concentrated yet their spending is small (see Gardner (1996), and below). Therefore, beyond organization, the stakes from favorable policy appear to be an important determinant of PAC spending.

An instructive case study of the influence of PAC money is that of the sugar lobby. Brooks, Cameron and Carter (1998) estimate a simultaneous model of voting on Sugar legislation and PAC contributions. Their objective is to investigate whether PAC contributions influence congressional voting and whether influencing congressional voting is a motivation for how PACs target their limited PAC spending. They find that during legislation of the 1985 and 1990 House sugar votes (the 1985 House amendment was to lower the loan rate by 1 cent per year until it reached 15 cents per pound, which was defeated $142-$ 263, and the 1990 House amendment was to lower the loan rate on sugar from 18 cents per pound to 16 cents per pound until 1995 which was defeated $150-271$ ):

(i) Both votes were responsive to sugar PAC contributions as well as counter lobbying by sweetener user PAC contributions. Further, the value of sugar production in their constituency also determined voting. Surprisingly, committee membership and ideology (party, which is shown to be a crucial variable in voting is excluded from the voting equation) appear to play no part in those house votes.

(ii) Sugar lobbying contributions targeted those with a high propensity to be pro sugar. The number of sugar farms in the recipients' district is an important determinant of sugar PAC contributions. Committee membership is statistically significant determinant of lobbying spending by sugar PACs (but the signs on the committee dummy reverse from 1985 to 1990).

\footnotetext{
${ }^{12}$ By comparison, Food Manufacturing and Forestry and Nursery had lower degree of concentration, while crop processing had the highest degree of concentration. (Cargill, Inc almost singularly represents Crop processing.)
} 
(iii) An interesting feature of this study is a third equation for counter lobbying by sweetener users. Committee membership, ideology, and party all play a role in 1990 but counter lobbying in 1985 is poorly explained by the variables included.

The 1990 sugar vote in the senate was responsive to, both, lobbying by sugar PACs and counter lobbying by sweetener PACs. The value of sugar production in the state was a statistically significant explanatory variable. The sugar PACs contributions targeted senators with a propensity to vote pro sugar. and targeted democrats and senators with seniority. Interestingly, lobbying competition from sweetener users increased sugar PAC contributions. Surprisingly, committee did not appear to matter. Counter lobbying by sweetener users largely responded by lobbying sugar PAC contributors. The main message from this result is that lobbying competition did play a role in the 1990 senate sugar vote.

Wheat, on the other hand, provides a case study of a sector that is politically not very strong, but has nevertheless managed to obtain subsidies. The persistence of these export subsidies via the costly and ineffective Export Enhancement Program (EEP) is analyzed in Gardner (1996). The political economy of the EEP is best viewed as organized pressure groups (wheat producers, other grain producers, wheat exporters) that stood to gain considerably from the EEP, winning at the expense of unorganized consumers and domestic grain domestic grain processors who lost between \$250-600 mn. annually. Another group that gained considerably were foreign governments, the buyers of subsidized wheat. Alternative policies that would have left the economy better off were politically less appealing. Gardner observes that in order for alternative policies to have a chance of succeeding politically, farmers must first buy into them, since the agricultural committees take their cue first and foremost from the farmers. If farmers are united, only organized public opposition can sway politicians. Such opposition has been absent for food subsidies in general, and the EEP in particular. Gardner also emphasizes the role played by other institutional features in maintaining the longevity of the EEP. The Office of Management and Budget designates EEP as budget-neutral because of large government stocks of wheat (in the past decade these stocks have depleted considerably). 


\section{C. $\quad$ PAC Spending Across Policymakers}

Ultimately, politicians deliver favorable policy. Thus, PAC spending may be directed at either putting into office politicians who have a high probability of delivering favorable policy, or gaining access to politicians who have influence over policy, or both. Whether PAC money influences election outcomes has been the subject of the number of studies. The results are mixed at best. The consensus in the literature seems to be shifting in the direction of PAC spending either as an instrument to gain access or as quid pro quo payments for policy.

Figure 4 breaks down contributions by party and chamber. ${ }^{13}$ Figure 4 shows the distribution of agricultural PAC contributions across candidates for the House and Senate over the five election cycles. Contributions to House and Senate candidates are further broken down by party. In the 1991-92 and the 1992-94 election cycles, two-thirds of agricultural PAC contributions went to House candidates and one-third to Senate candidates. Among House candidates Republicans and Democrats received almost equal contributions. Among Senate candidates Ag PACs appear to favor Republicans.

This picture changed dramatically during the 1995-96 election cycle. Total Ag PAC contributions were $15 \%$ greater than the previous cycle. Republican candidates for House and Senate seats got the lion's share of those contributions. Ag PACs thus appeared to facilitate the eventual Republican majority in both the House and Senate, the first time in decades that the Republicans enjoyed majorities in both houses. It would be tempting to conclude that $\mathrm{Ag}$ PAC money was able to influence electoral outcomes, a view that goes against the grain in the literature. In anticipation of Republican majorities in the House and Senate led agricultural PACs (and most other corporate PACs) to contribute heavily to Republicans. Republicans were viewed as pro-business and to be more likely providers of favorable policy than democrats. Ag PAC contributions in the 1997-98 and the 1999-00 election cycles continued to have a Republican skew, though total contributions declined from the 1995-96 levels.

\footnotetext{
${ }^{13}$ Agricultural PACs are defined as related to all the agriculturally related sectors depicted in Figure 3. They include Farm products, Ranch PACs, Ag Services, Crop Processing, Distribution, ForestryNursery, Farm Equipment and Manufacturing.
} 
Figure 4: TotalAG PAC C ontributions to House and Senate. B y Party.1991.2000

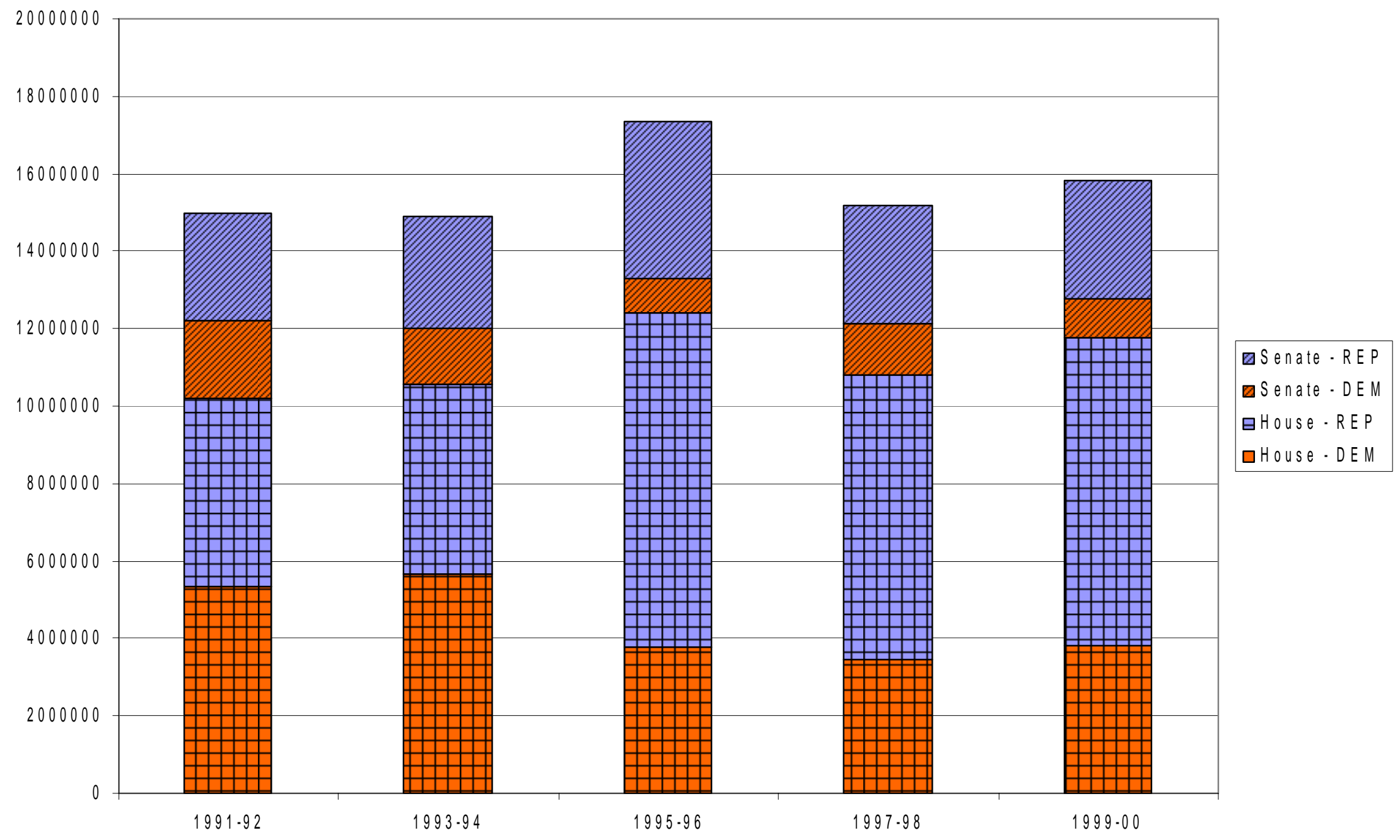


Figures 5-9 detail whom agricultural PACs target politically. They present a break down of agricultural PAC money in each election cycle by individual House and Senate recipients. In each election cycle, in the two chambers the top 20 recipients of $\mathrm{Ag}$ PAC money are named, their Ag PAC receipts indicated, their party, state and, importantly, their membership (if any) to the Agricultural committee and its subcommittees are indicated.

Figure 5 shows the top 20 House recipients of Ag PAC money during the 1991-92 election cycle. A striking feature is the presence of many House Agriculture committee members on this list. In the 1991-92 Agriculture committee there were 45 seats (27 Democrats, 18 Republicans). Of these, fifteen appeared in the top-20 list. The 1991-92 Agriculture committee comprised eight subcommittees. ${ }^{14}$ The Agriculture chair (de la Garza ) and three committee chairs (Huckaby, Stenholm, Rose) were on the top-20 list. This pattern of giving to candidates strongly suggests that Ag PAC money sought influence. Ag PACs clearly targeted members of the Agriculture committee, specifically those wielding influence over agriculture policy. The amounts themselves are not inconsequential. For many candidates on the top-20 list Ag PACs are a major source of campaign contributions. Figure 10 indicates that contribution from Ag PACs delivered anywhere between 8\% (Fazio) and 60\% (de la Garza) of the total PAC money received by candidates in this "Ag PAC top 20". ${ }^{15}$ It is thus not unlikely that the Ag PAC money may have played a role in influencing election outcomes. Figure 11 similarly shows that the top 20 recipients of Ag PAC contributions during the 199900 election cycle got significant shares of their total PAC contributions from Ag PACs.

\footnotetext{
${ }^{14}$ During 1991-92, the House Agriculture subcommittees were: Conservation, Credit and Rural Development (CCRD), Cotton, Rice and Sugar (CRS), Department Operations, Research and Foreign Agriculture (DORFA), Domestic Marketing, Consumer Relations and Nutrition (DMCRN), Forest, Family Farms and Energy (FFFE), Livestock, Dairy and Poultry (LDP), Peanuts and Tobacco (PT), Wheat, Soybeans and Feed Grains (WSFG). The 1993-94 subcommittees were Department Operations and Nutrition (DON), Environment, Credit and Rural Development (ECRD), Foreign Agriculture and Hunger (FAH), General Farm Commodities (GFC), Livestock (L), and Specialty Crops and Natural Resources (SCNR). House subcommittees in 1995-96 and 1997-98 were Department Operations, Nutrition and Foreign Agriculture (DONFA), GFC, Livestock, Dairy and Poultry (LDP), Risk Management and Specialty Crops (RMSC), Resource Conservation, Research and Forestry (RCRF). 1999-00 subcommittees were Department Operations, Oversight, Nutrition and Forestry (DOONF), General Farm Commodities, Resource Conservation and Credit (GFCRCC), Livestock and Horticulture (LH), Risk Management, Research and Specialty Crops (RMRSC).

${ }^{15}$ The total receipts were generally higher because the candidates received not just from PACs but also from individuals.
} 
Whether agricultural PAC money influenced electoral outcomes is left as an open issue deserving further research.

Returning to Figure 5.1 it should be noted that there are candidates on this top $20 \mathrm{Ag}$ money list who are not members of Ag committee (Fazio, Edmondson, Bliley, Bonior and Anthony). However, they were all (with the possible exception of Anthony) from congressional districts with influential agricultural constituents (CA, OK, VA, MI). For example, Fazio's district (CA, district 3) was among the 30 leading congressional districts by market value of agricultural products sold in 1997 (1997 Census of Agriculture), and Edmondson's district was among the thirty leading Cattle and Calves districts

Finally, contribution to Ag committee members, and membership on Ag committees are not independent of each other. The received wisdom in the literature on the political economy of agriculture policy is that representatives from districts with agriculturally influential constituencies seek out membership on agriculture committees and lobby hard for positions of influence on its subcommittees. Consequently, they are in position to influence agriculture policy especially during the five-yearly Farm Bill legislations. Their influential positions endear them to PAC influence. Ag PAC contributions and the ability to influence agriculture policy are therefore simultaneously determined.

Figures 5.2-5.5 depict the top-20 Ag PAC list from the four election cycles between 1993 and 2000. They reinforce the foregoing observations. In each of these cycles, giving to members of the House agriculture committee is highlighted. And candidates who appear in the list but are not members of the agriculture committee belong to districts with agriculturally influential constituencies.

An interesting pattern emerges when comparing the combination of party with committee membership across the five election cycles. A natural experiment that the cycles provide is the switch from Democratic to Republican majority in 1995 and thereafter. Whereas, the top-20 recipients who were agriculture committee members comprise largely Democrats during the 1991-92 and 1993-94 congresses, they were mainly Republicans in the three later congresses. This pattern reinforces the view that Ag PAC money was not party driven (or ideological) but rather sought influence. 
Figure 5.1: Top 20 HOUSE Recipients of A G PAC money: 1991.92 Election Cycle

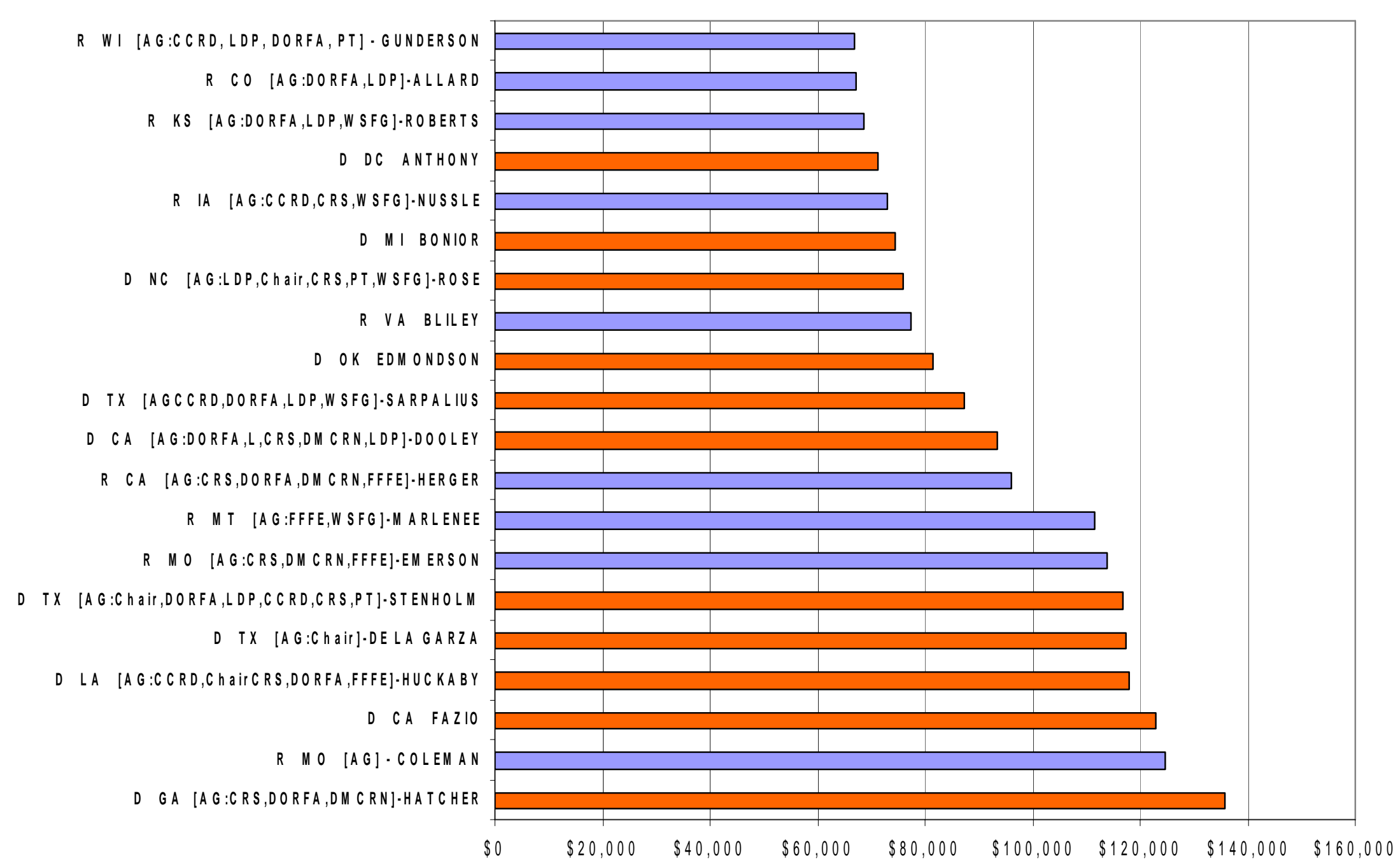


Figure 5.2: Top 20 HOUSE Recipients of AG PAC money: 1993.94 Election Cycle

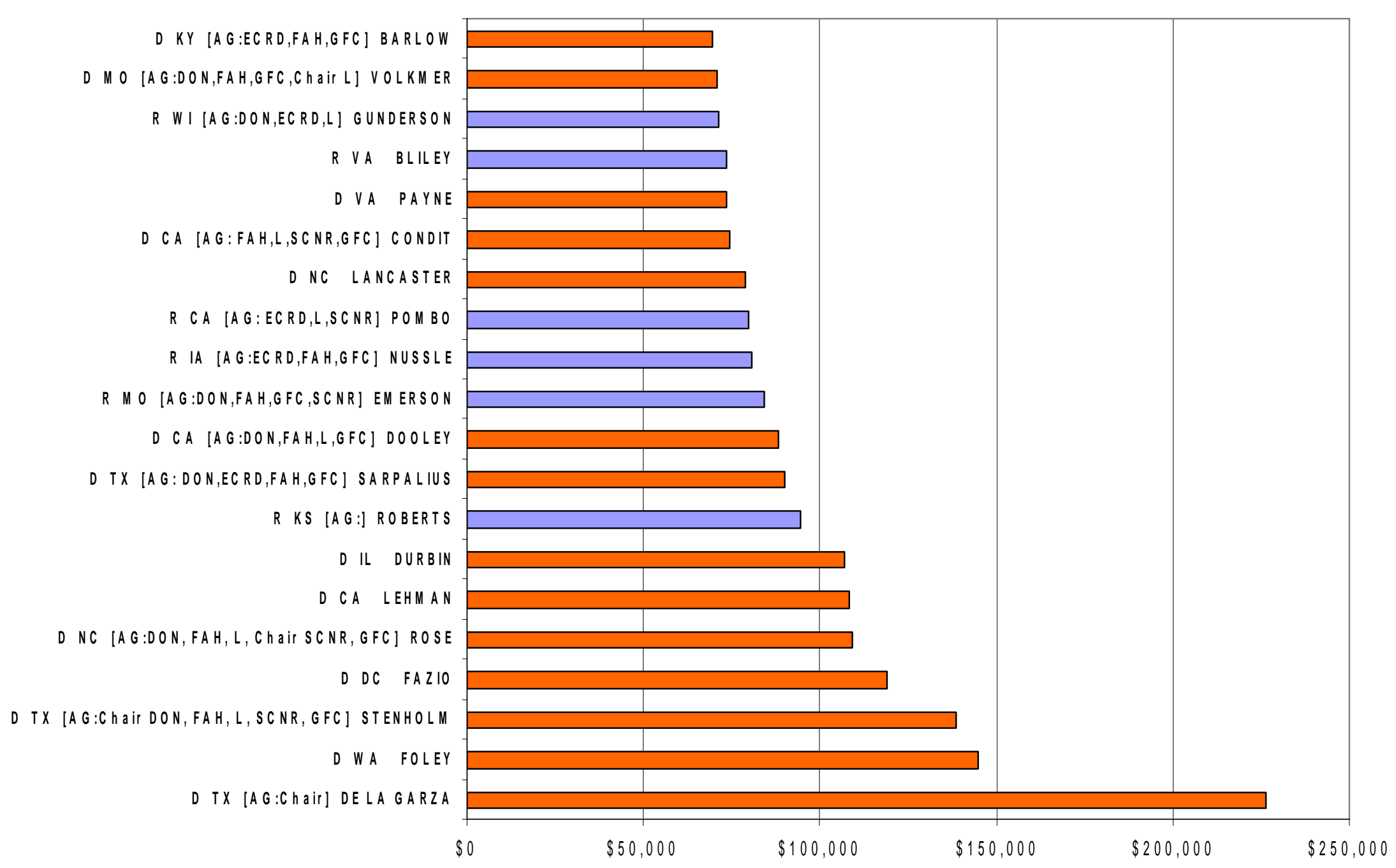


Figure 5.3: Top 20 HOUSE Recipients of AG PAC m oney: 1995.96 Election Cycle

R ID [AG:RCRF] CHENOWETH

$R$ ID [AG:DONFA, RCRF] CRAPO

D MN [AG:LDP, RCRF] PETERSON

R GA NORWOOD

R NM SKEEN

R CA RIGGS

R OH $[A G: G F C, L D P] B O E H N E R$

R GA GINGRICH

$R$ TX [AG:GFC, RM SC] COM BEST

$R$ CA $[A G: L D P, R M S C, R C R F] P O M B O$

$R$ IA [AG:GFC, DONFA] LATHAM

D CA [AG:DONFA, RCRF] CONDIT

$R M O[A G: G F C, D O N F A]$ EMERSON

D CA FAZIO

R IL $[A G: R M S C, D O N F A] E W I N G$

$R G A[A G: G F C, R M S C]$ CHAM BLISS

R OR SM ITH

D CA [AG:GFC,LDP] DOOLEY

D TX [AG:GFC,RCRF] STENHOLM

R KS [AG Chair] ROBERTS

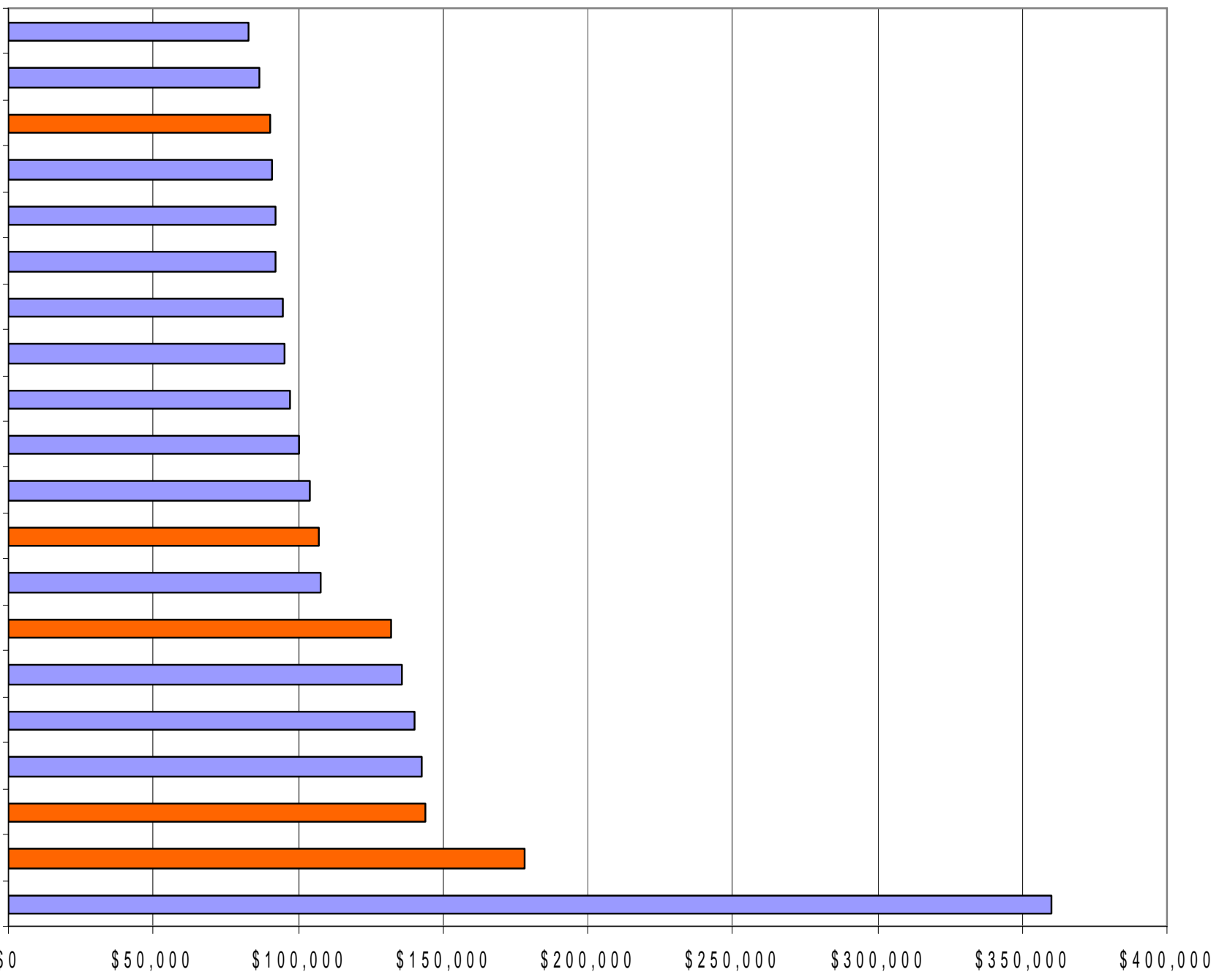


Figure 5.4: Top 20 HOUSE Recipients of AG PAC m oney: 1997.98 Election C ycle

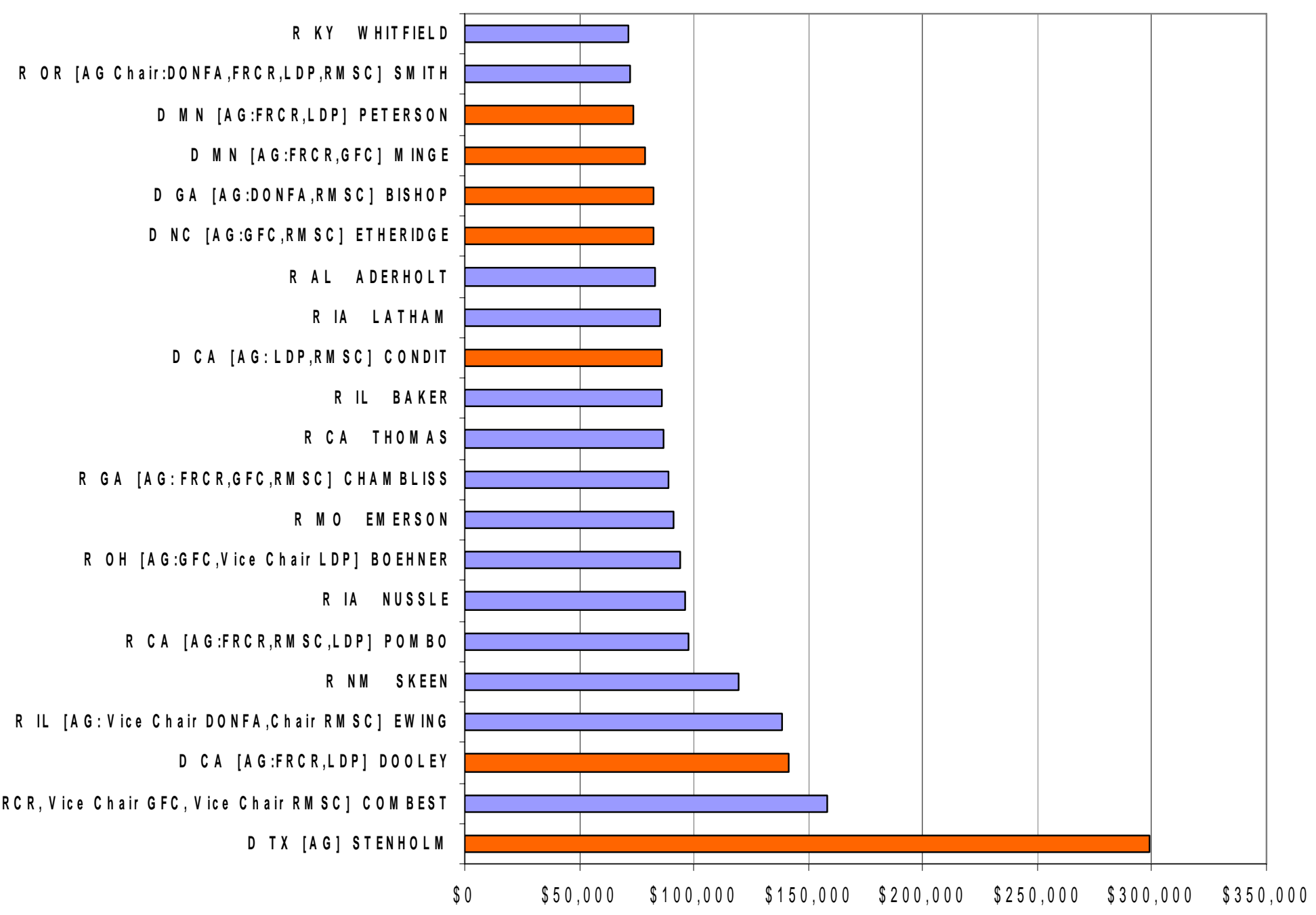


Figure 5.5: Top 20 HOUSE Recipients of AG PAC m oney: 1990-00 Election C ycle

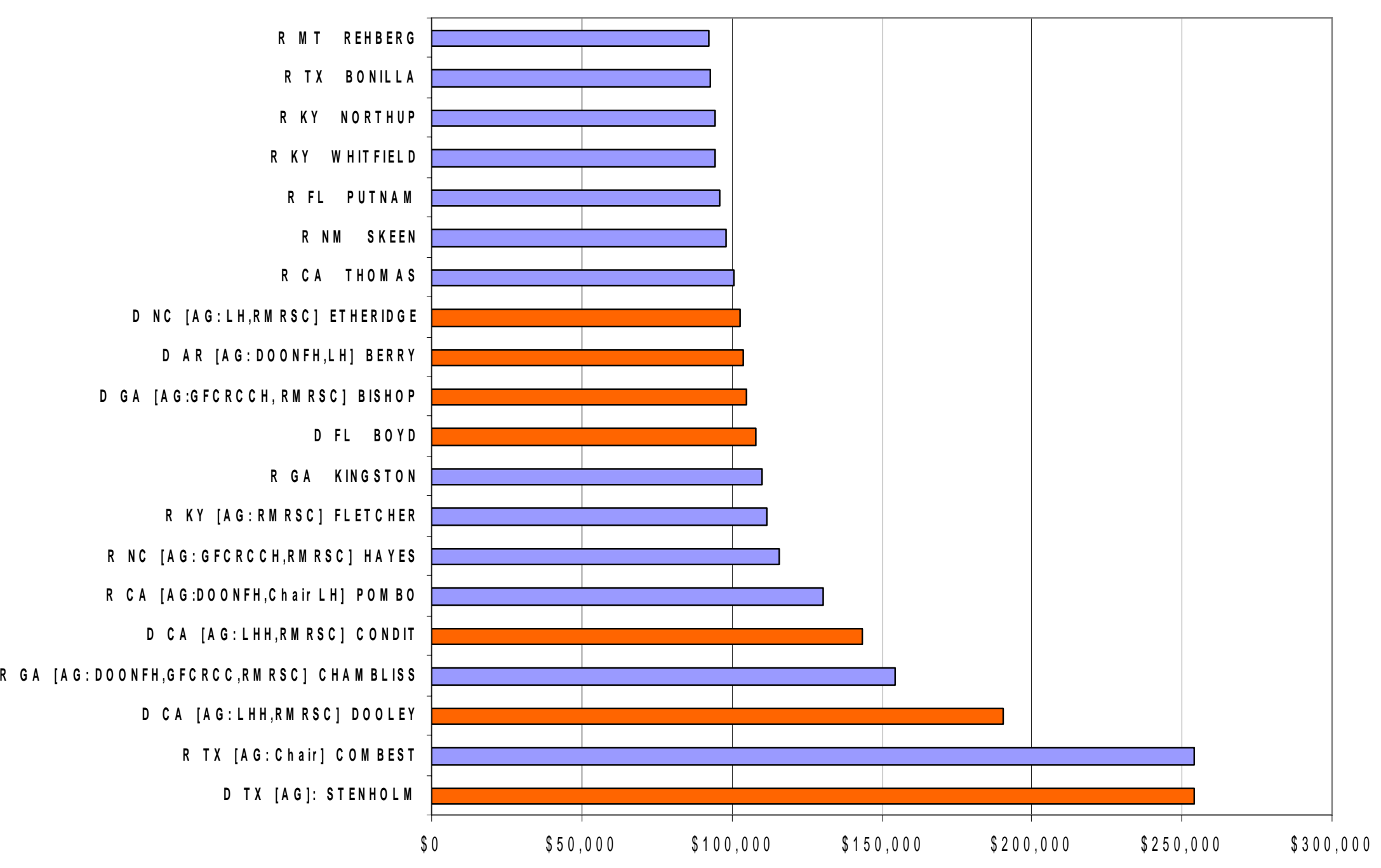


The pattern of giving to Senate candidates appears to be very similar to the pattern of giving to candidates up for House elections. That is, candidates on the top-20 Ag PAC Senate list get roughly similar contributions as do candidates on the top-20 Ag PAC House list. Hence, Ag PACs view these top-20 senators and representatives approximately equally. If the theory that contributions are made in exchange for political favors is correct, then Ag PACs view senators as having as much power to provide political favors as do representatives. If the theory that contributions mainly target access to political influence is correct, then Ag PACs view senators and representatives approximately equally in the amount of influence each dollar of contributions is likely to buy. This quantity of influence, in turn, depends on the provision of information to politicians that is perceived by them to be both, costly and valuable.

One important difference between Ag PAC contributions to Senate and House candidates is that Ag PAC contributions to Senate candidates as a percentage of their total PAC receipts do not exceed $25 \%$ and is generally lower than $10 \%$ even for the largest recipients of Ag PAC contributions. This is not surprising since, on average a Senate election costs roughly ten times as much as a house election ${ }^{16}$. This is depicted in Figure 6.1 and 6.2 for the House and in Figures 8.1 and 8.2 for the Senate. However, the evidence that Ag PACs view senators and representatives equally while making campaign contributions appears to be fairly strong evidence that Ag PACs do not generally seek to influence election outcomes. If influencing elections were the true motive, then we should see Ag PAC receipts as a proportion of total PAC receipts to be roughly similar across House and Senate candidates. But this implies that contribution to Senate candidates should be ten times higher than they actually are.

\footnotetext{
${ }^{16}$ In 1992 the average winning Senate candidate spent \$3.9 mn. while the average House winning candidate spent $\$ 0.5 \mathrm{mn}$., approximately an 8:1 ratio,. The average Senate loser spent $\$ 2.0 \mathrm{mn}$. while the average House loser spent \$.2 mn., a 10:1 ratio. In other election cycles the average Senate to House spending ratios (winners plus losers) 10:1 in 1994, 8:1 in 1996, 9.4:1 in 1998, 10:1 in 2000. Further, total PAC receipts as a proportion of total campaign spending averaged approximately $20 \%$ for winning Senate candidates while they averaged approximately $50 \%$ for winning House candidates. These figures are computed from in formation on the opensecrets.org (opensecrets 2002) web site.
} 
Figure 6.1: Top 20 House AG PAC Recipients: R atio of AG PAC to TotalPAC reciepts, 1991.92

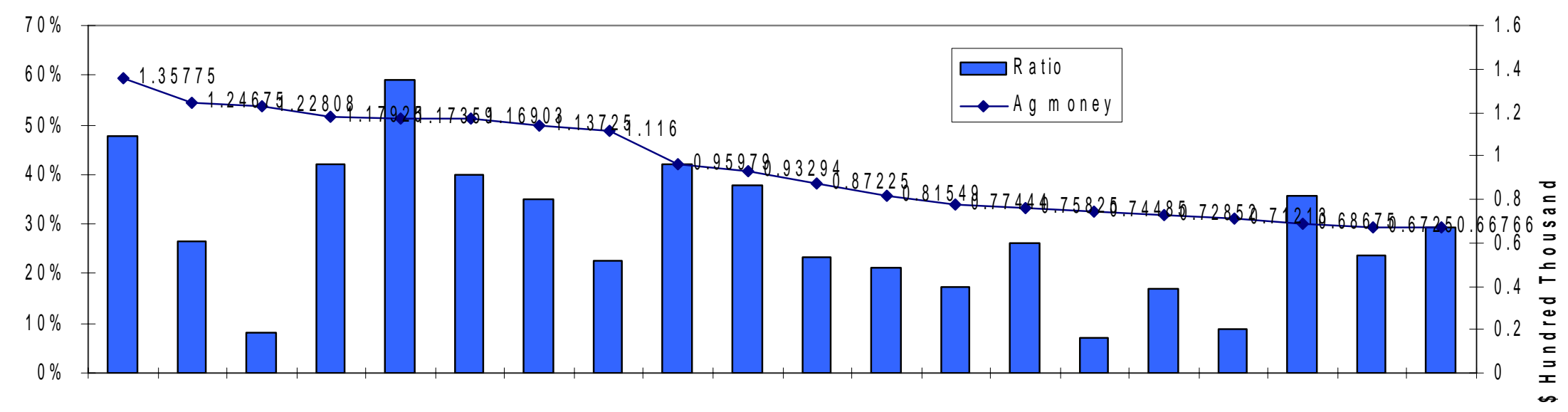

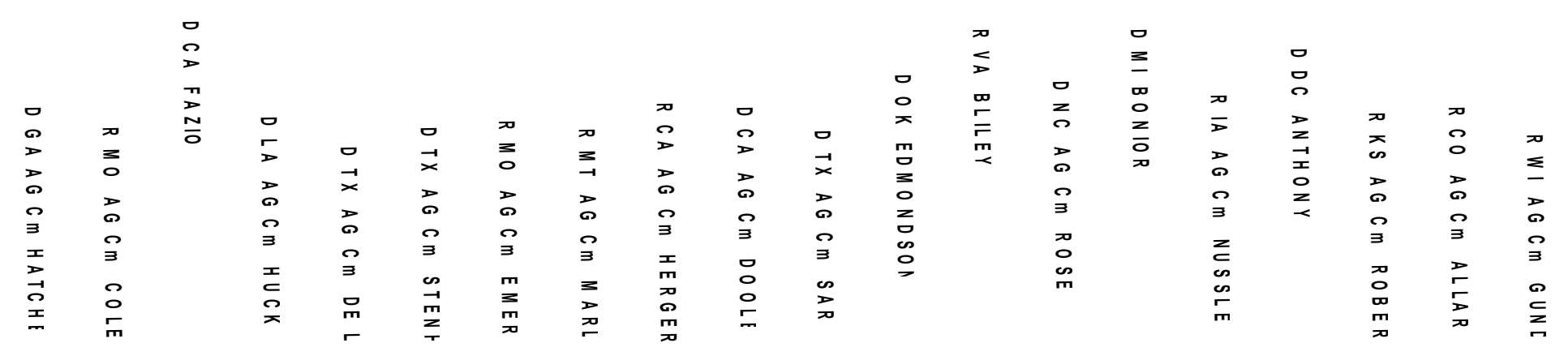


Figure 6.2: Top 20 House AG PAC Recipients: Ratio of AG PAC to Total PAC reciepts, 1999.00

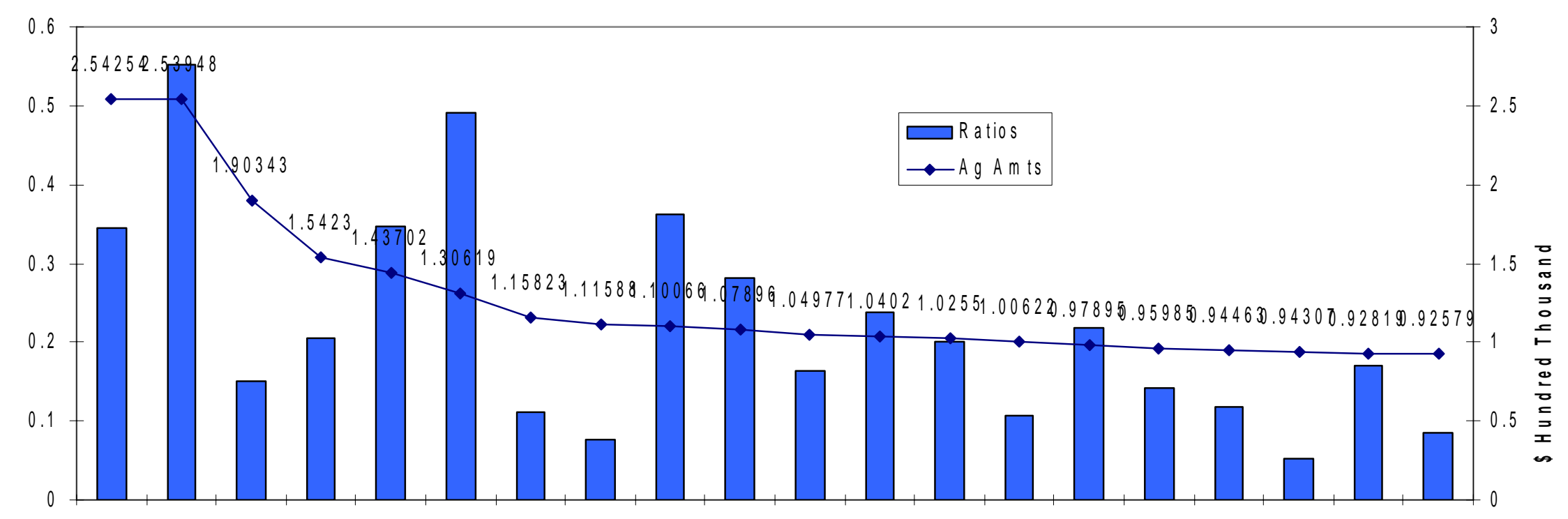

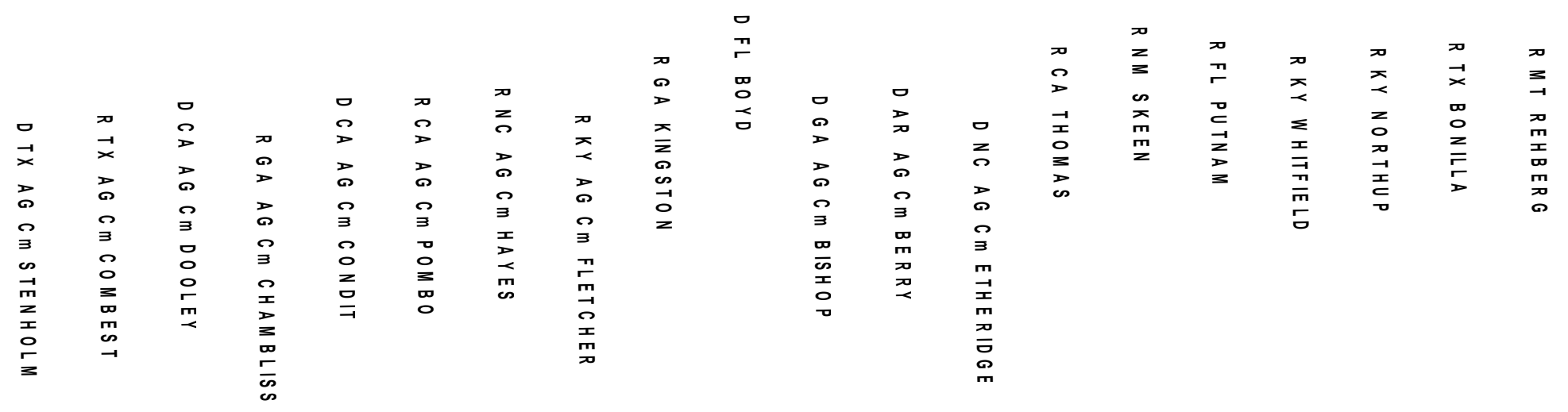


Figures 7.1-7.5 name the Senate candidates that were the largest recipients of Ag PAC money over the five election cycles between 1991-00, and indicate the amounts they received. It is instructive to compare Figure 7.1 with its House counterpart, Figure 5.1. The amount of Ag PAC money received by Senate candidates (Figure 7.1) is approximately of the same magnitude as that received by House candidates (Figure 5.1) on average. However, there are distinct differences in the characteristics of these top-20 Ag PAC recipients. Many more members of the Agriculture committee appear on the House top-20 Ag PAC list in Figure 5, while relatively fewer in number appear on the Senate top-20 Ag PAC list in Figure $7.1^{17}$. Indeed, in the 1993-94 election cycle (Figure 7.2) only two of the top-20 Ag PAC senate recipients belong to the Senate Agriculture, Nutrition and Forestry committee. During enactment of 1995 Farm Bill the top-20 Ag PAC list comprised many more senators from Agriculture, Nutrition and Forestry committee as Figure 7.3 clearly indicates. Nonchalance about committee membership returned in the next two election cycles with fewer committee members on the top-20 Ag Pac lists of Senate candidates during those cycles (Figure 7.4 and 7.5).

The overall message is that membership on the Agriculture, Nutrition and Forestry committee did not confer especially great benefits upon Senators. It accords well with the generally held view that committee membership matters more to congressmen in the House than in the Senate. The opportunity for vote trading and logrolling is greater in the Senate than in the House. Senators, regardless of their committee affiliations, have greater individual influence over legislation than do Representatives, who derive their power from memberships

\footnotetext{
${ }^{17}$ The Senate Agriculture, Nutrition and Forestry committee is smaller than the House Agriculture committee. It comprises eighteen senators (in 1991-92 the party ratio was 10 Democrats to 8 Republicans). This is about two-fifths the size of the House Agriculture committee. During 1991-92, the following Senate Agriculture, Nutrition and Forestry subcommittees were formed: Conservation, Credit and Rural development (CCRD), Cotton, Rice and Sugar (CRS), Department Operations, Research and Foreign Agriculture (DORFA), Domestic Marketing, Consumer Relations and Nutrition (DMCRN), Forests, Family Farms and Energy (FFFE), Livestock, Dairy and Poultry (LDP), Peanuts, and Tobacco (PT), Wheat, Soybeans and Feed Grains (WSFG). At the beginning of every new congress the entire subcommittee structure is significantly altered. In the 1993-94 the sub committees were: Agricultural Credit (AC), Agricultural Production and Stabilization of Prices (APSP), Agricultural Research, Conservation, Forestry and General Liquidation (ARCFGL), Domestic and Foreign Marketing and Product Promotion (DFMPP)Nutrition and Investigations (NI) and Rural Development and Rural Electrification (RDRE). The subcommittees in 1995-96, 1997-98 and 1999-00 were: Forestry, Conservation and Rural Revitalization (FCRR), Marketing, Inspection and Product Promotion (MIPP), Production and Price Competitiveness (PPC), and Research, Nutrition and General Legislation (RNGL).
} 
on influential committees such as the House Agriculture committee. Therefore, the top-20 Senate Ag PAC lists in Figures 7.1-7.5 contain names of Senators who are from states with influential agricultural constituencies but may or may not be members of the Agriculture, Nutrition and Forestry committee. A case in point is the absence of the chair of this committee in 1991-92 (Sen. Leahy, VT, ranked $33^{\text {rd }}$ among Ag PAC recipients), but the presence of Senators from Missouri which was the $12^{\text {th }}$ ranked state in 1992 according to market value of agricultural products sold (U.S. Department of Census, 1997), Wisconsin, ranked $8^{\text {th }}$, Oklahoma ranked $17^{\text {th }}$, Indiana ranked $11^{\text {th }}$, Arkansas ranked $13^{\text {th }}$, Pennsylvania ranked $18^{\text {th }}$, and Georgia ranked $19^{\text {th }}$. Senators from other states appearing in Figure 7.1 but not ranked highly according to total value of agricultural products sold were nevertheless ranked highly in output of specialized products. Thus, Senators were sought by: potato interests in Idaho, tobacco and livestock interests in Kentucky, peanut and poultry interests in Alabama, tobacco interests in South Carolina.

Nor does it appear that there was a strong desire among senators to become members of agriculture committees. Representing states with strong agriculture interests was sufficient to guarantee them Ag PAC money. This was especially true among the top-20 Ag PAC Senate recipients in the 1993-94 (Figure 7.2), 1997-98(Figure 7.4) and 1999-00 (Figure 7.5) election cycles. Figure 7.2 for example indicates that agriculturally rich states represented by strong Ag PACs (Texas, Montana, Washington, California) gave to their Senate candidates regardless of committee membership. The same was true of the 1997-98 and 1999-00 election cycles. A reasonable conclusion is that there does not appear to be simultaneity between the amount of PAC spending and committee membership. Evidence of that simultaneity appears to be much stronger for House candidates. 
Figure 7.1: Top 20 SENATE Recipients of AG PAC M oney.1991.92 Election Cycle.

D SD [AG:AC, RDRE, Chair ARGL]-DASCHLE

D SC HOLLINGS

D LA BREAUX

R GA COVERDELL

D AL SHELBY

R AZ MCCAIN

R PA SPECTER

R ID KEMPTHORNE

D AR BUMPERS

D KY FORD

$R$ IN COATS

R OK NICKLES

$R$ IA $[A G: A C, A P S P, D F M P P] \cdot G R A S S L E Y$ $R \quad D C$ [AG:APSP,NI,ARGL]-DOLE R W I KASTEN

R DC CHANDLER

D ND [AG: DFMPP, Chair AC,APSP]-CONRAD

R MO BOND

$D \quad D C[A G: C h$ air $C F, D F M P P, N I]-F O W L E R$

$R \quad C A[A G: A P S P, A R G L, D F M P P] \cdot S E Y M O U R$
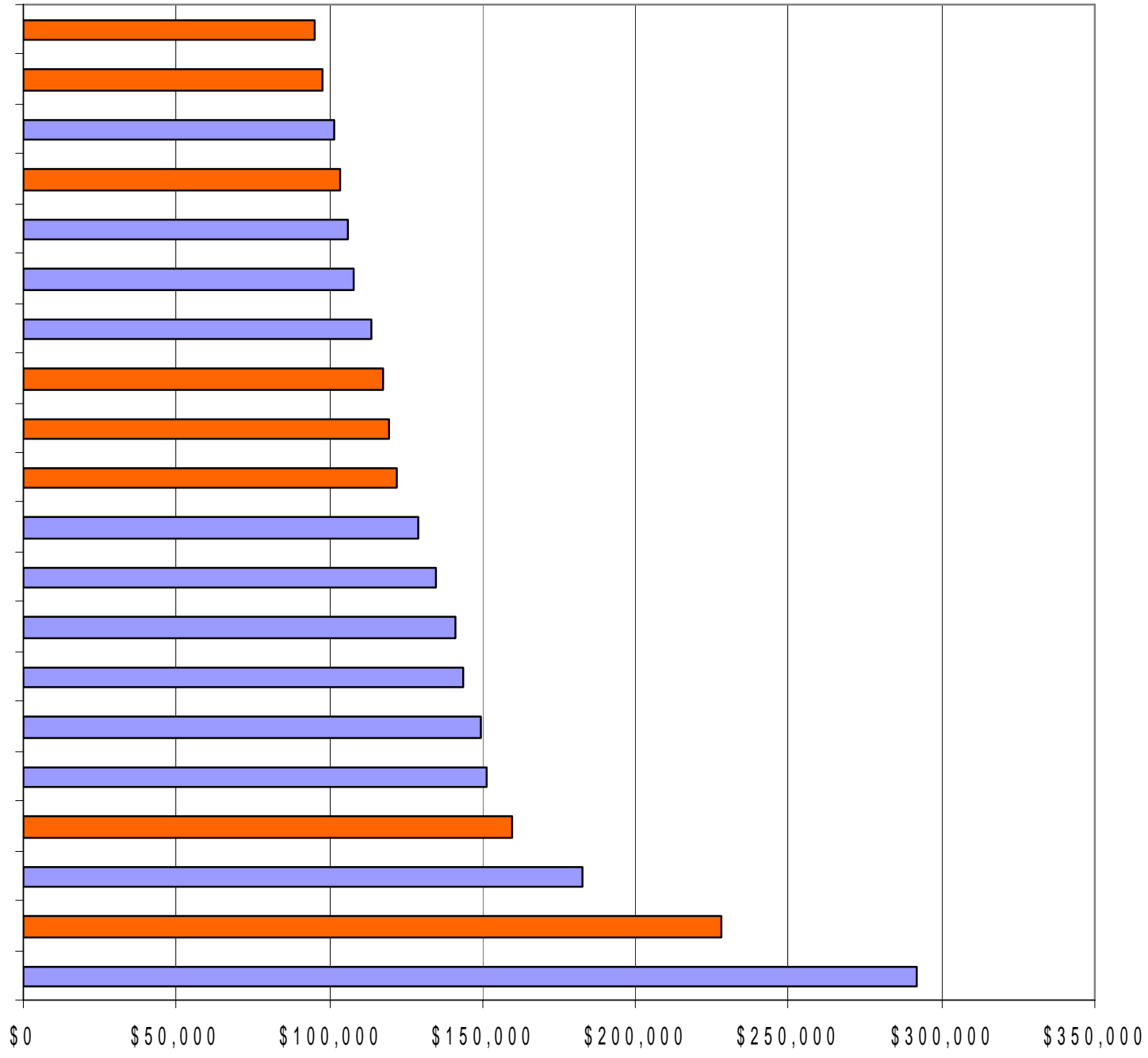
Figure 7.2: Top 20 SENATE Recipients of AG PAC M oney. 1993.94 Election Cycle.

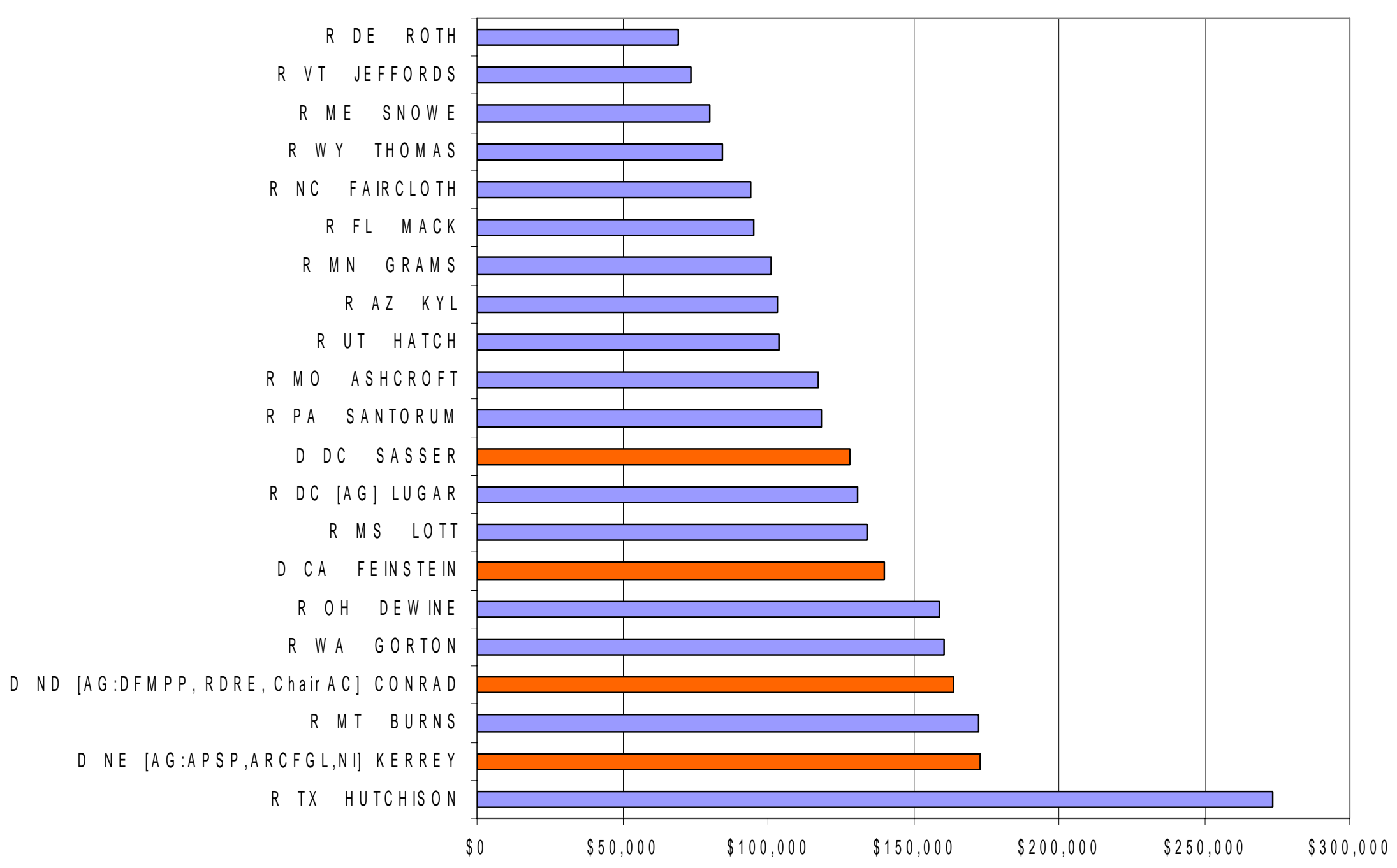


Figure 7.3: Top 20 SENATE Recipients of AG PAC M oney.1995.96 Election Cycle.

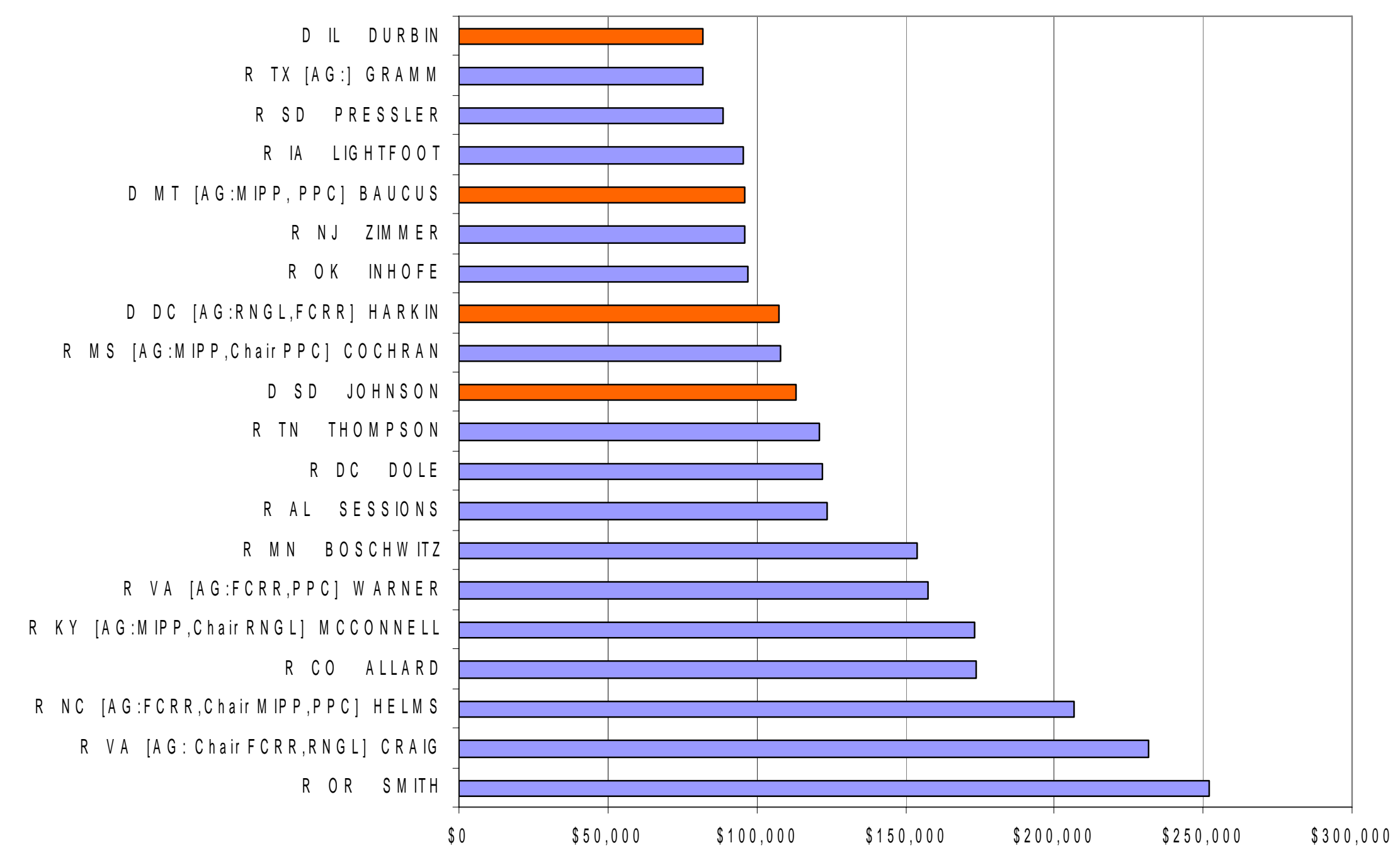


Figure 7.4: Top 20 SENATE Recipients of AG PAC M oney.1997.98 Election Cycle.

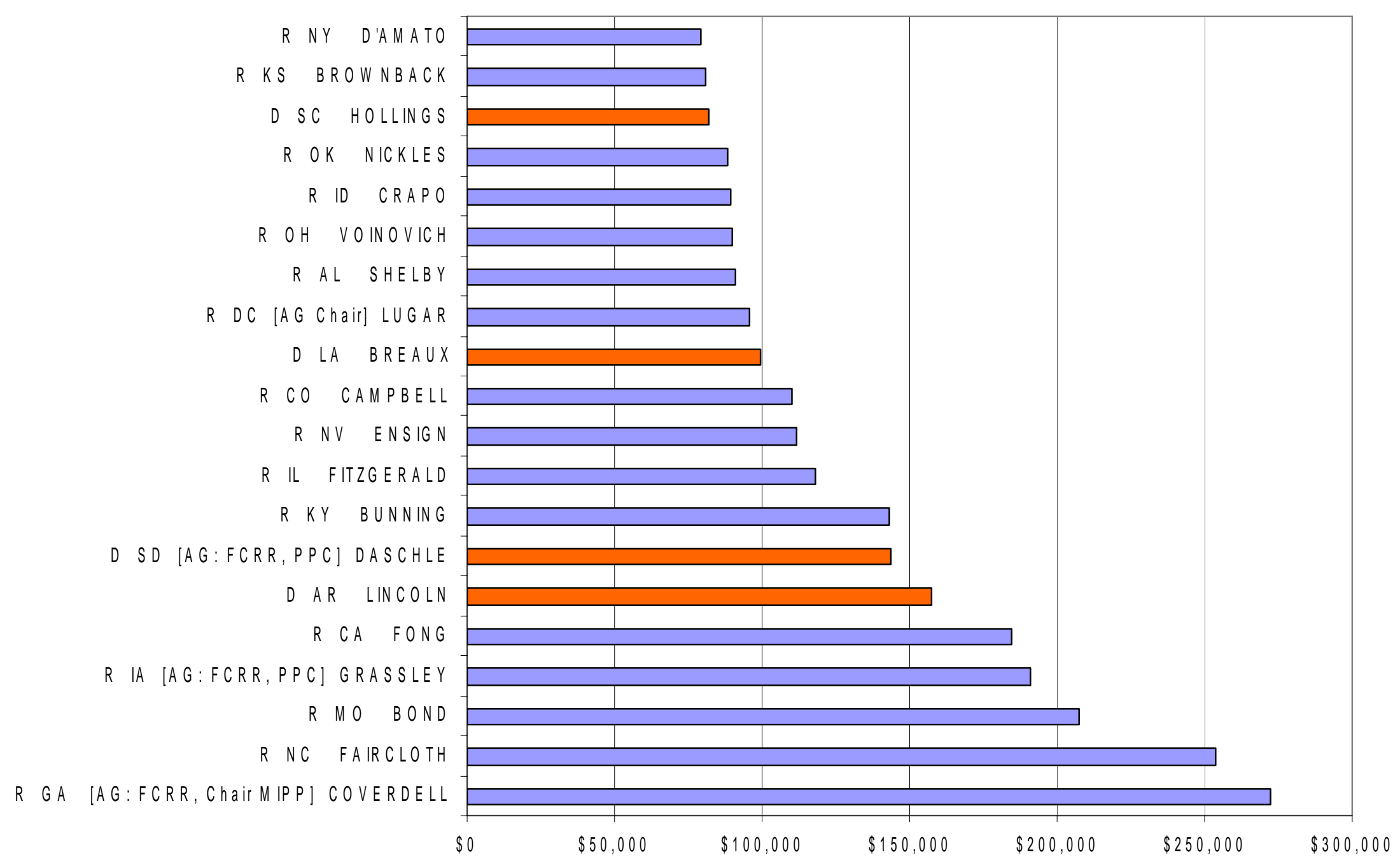


Figure 7.5: Top 20 SENATE Recipients of AG PAC M oney. 1999.00 Election Cycle.

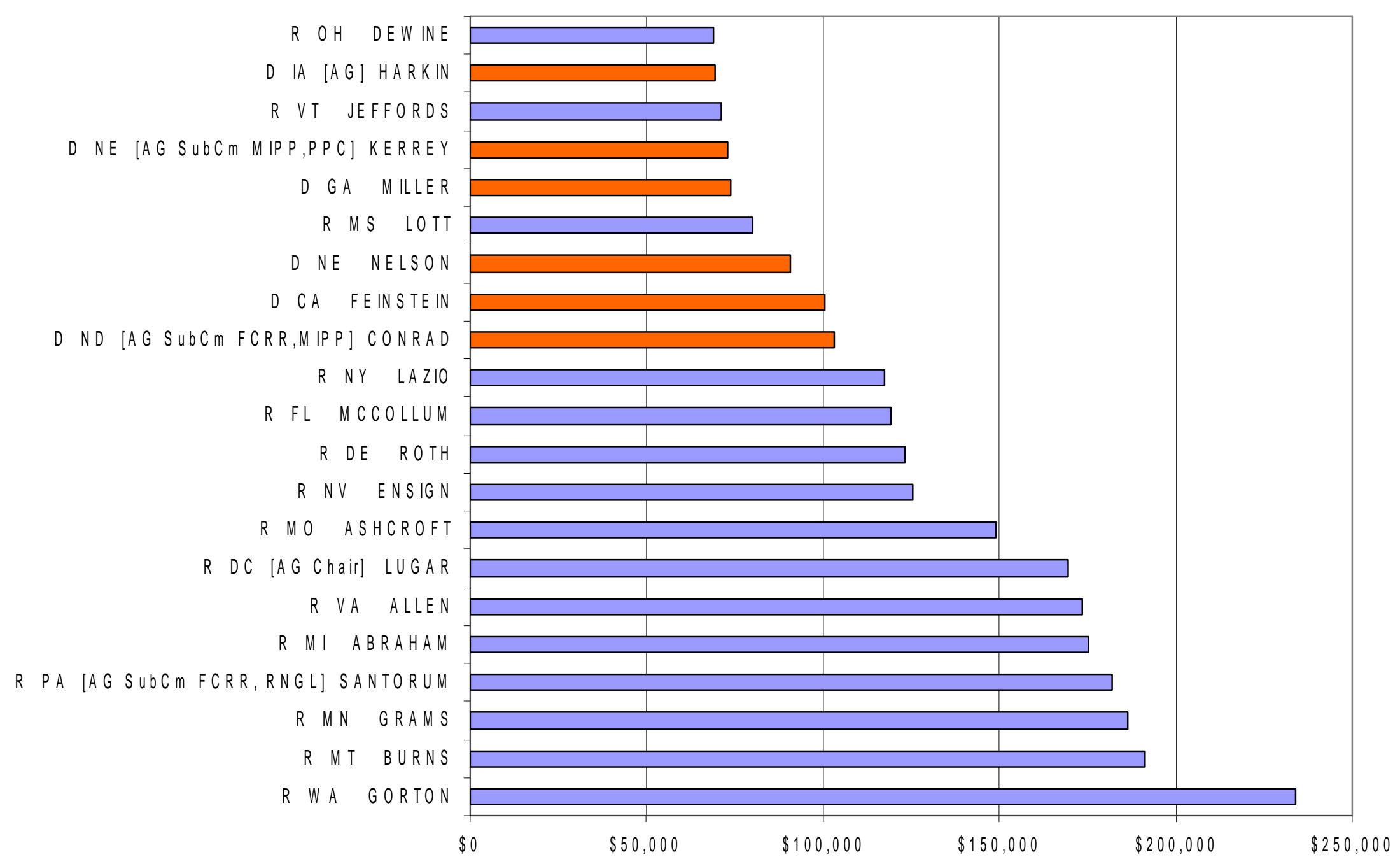


Figure 8.1: Top 20 Senate AG PAC Recipients: Ratio of AG PAC to TotalPAC receipts, 1991.92

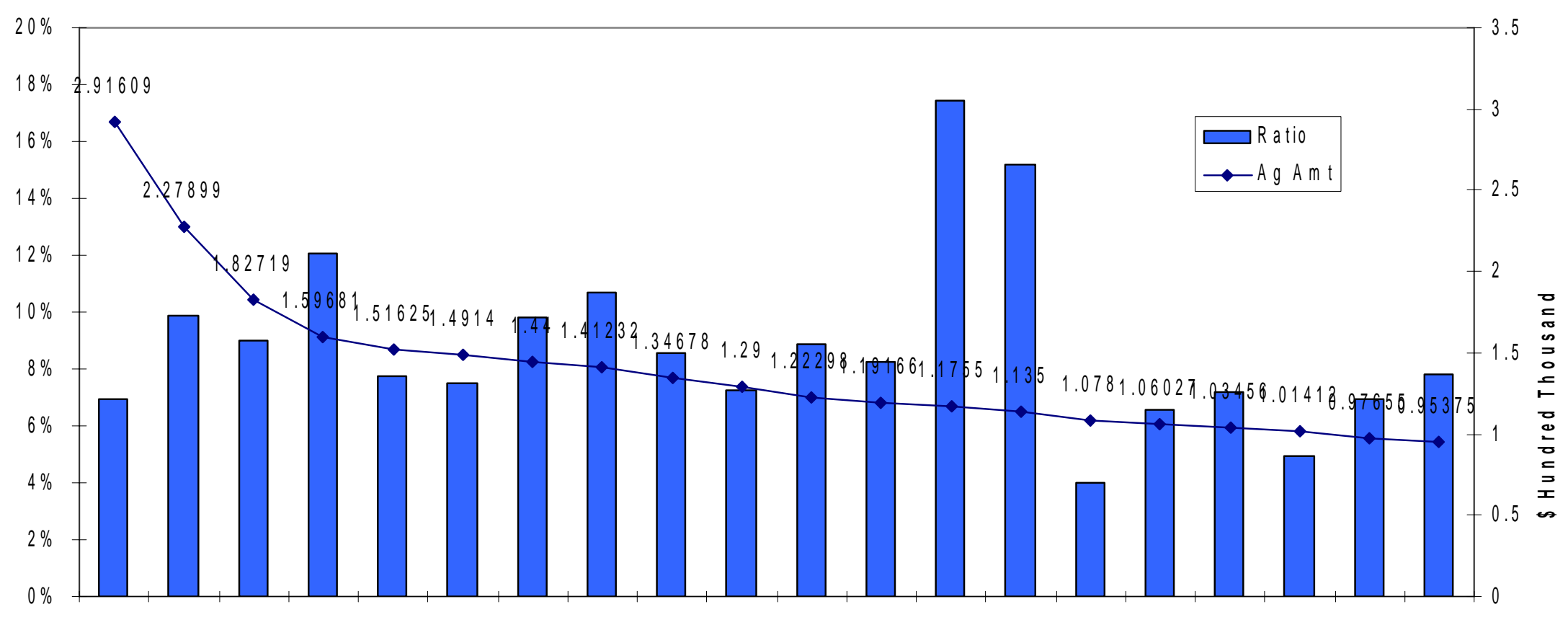

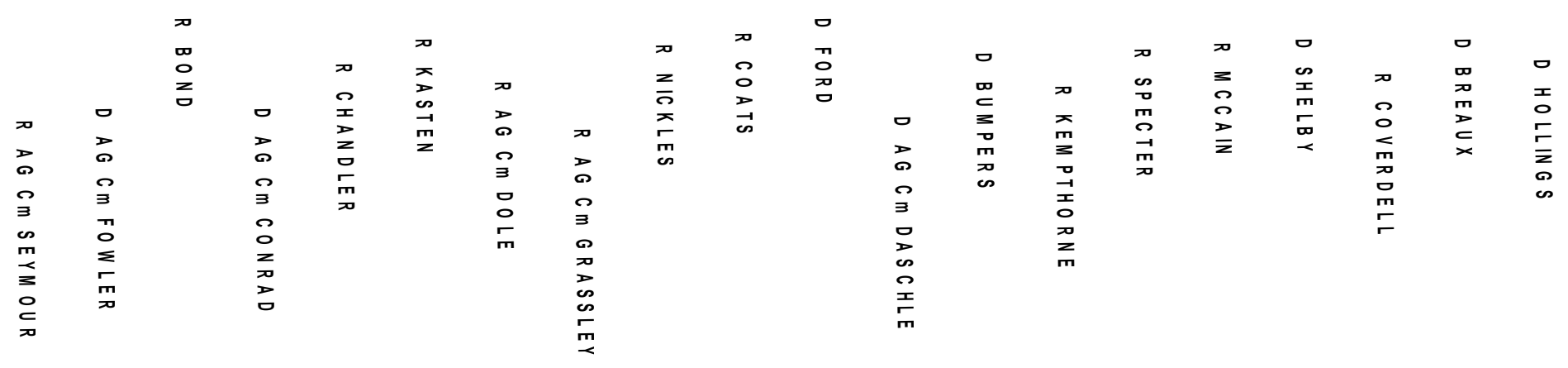


Figure 8.2: Top 20 Senate AG PAC Recipients: Ratio of AG PAC to TotalPAC receipts, 1999.00

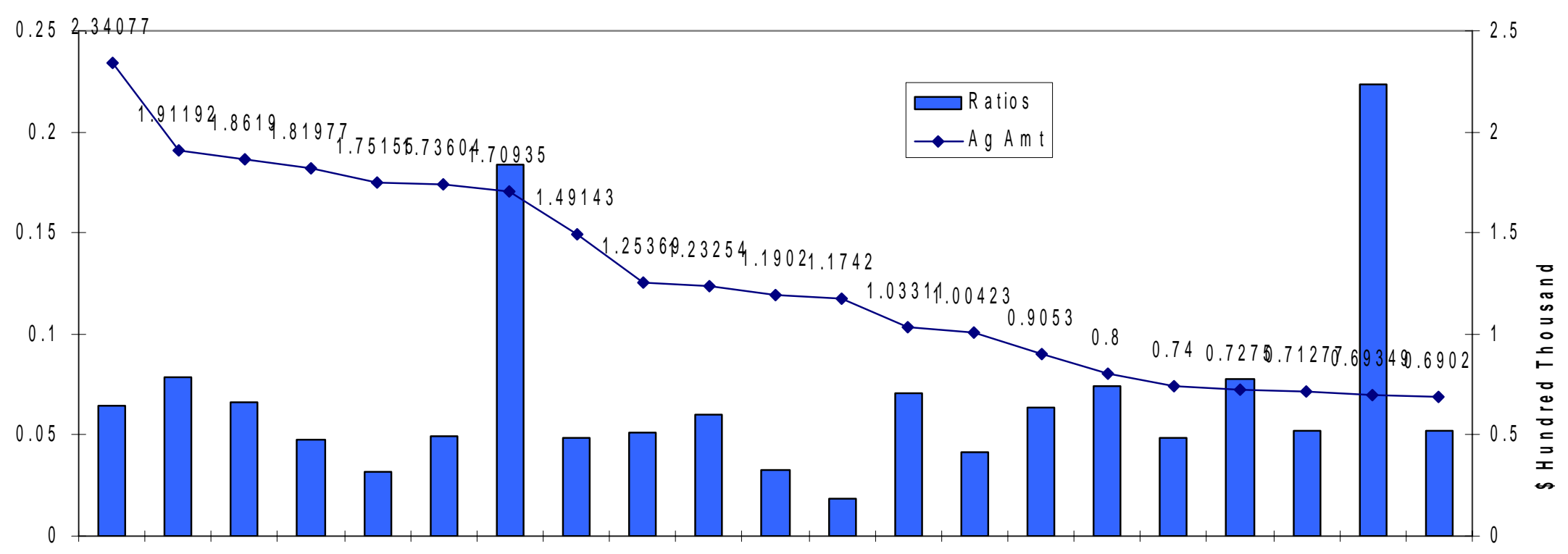

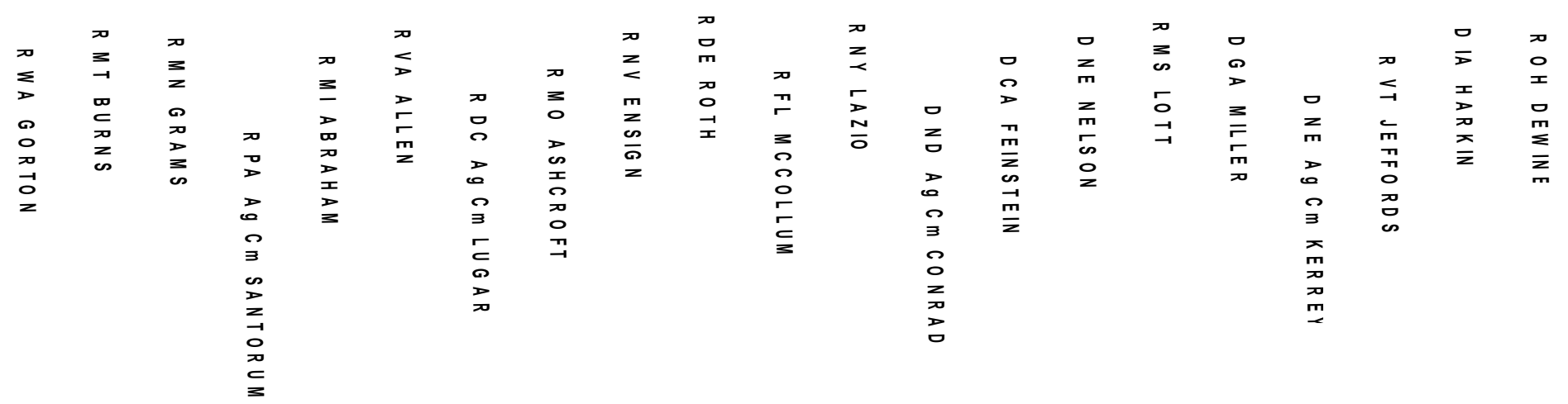


However, the study by Van Doren, Hoag and Field (1999) finds that committee membership does confer benefits to Senators. They compute PAC spending by sub-sectors of agriculture during 1989-94 with the objective of studying what characteristics of Senators influence the pattern of contributions. They find membership on the Senate Agriculture Committee and the Agriculture, Rural Development and Related Agencies sub-committee of the Senate Appropriations Committee to be the most important determinant. Membership on the Senate Agriculture committee confers the ability to receive $\$ 13,000$ more in agricultural PAC contributions, and membership on the Appropriations Sub-committee confers an advantage of over $\$ 4,000$. Some agricultural sub-sectors contribute far more to committee members than do others. The study also finds that while the average legislator only received about $7 \%$ of his or her PAC funding from Ag PACs, agricultural committee members receive almost 14\% of their PAC funding from Ag PACs. Of all the sub sectors, food manufacturing valued membership to agricultural PACs the most, paying on average $\$ 2,332$ per year to committee members. Next in line were sugar cane and sugar beet producer PACs, at $\$ 1,617$, followed by agricultural services at $\$ 1,288$. Membership to Agriculture Appropriations sub committee also mattered, leading to an aggregate annual contribution of $\$ 4,215$ more than non-members. Agricultural services PACs were the leaders in this category, paying on average $\$ 1,094$ more, followed by dairy PACs at $\$ 891$. Van Doren et al. also find the percentage of state under farmland to be a consistent indicator of PAC contributions. Thus with every $1 \%$ increase in $\%$ farmland, holding everything else constant, the senator from that state could expect to get $\$ 124$ more per year. Sugar cane and sugar beet (\$27) and tobacco (\$22) were the highest payers. Dairy producers came in third at $\$ 18$.

While their estimates are statistically significant, the effects are small relative to the total campaign contribution these committee members receive. The lobbying data we have analyzed suggests that a similar exercise for House Agriculture committee members would show committee-effects that are not only statistically significant, but also economically large.

To close, it is pertinent to ask whether informational lobbying might not be a useful alternative to the quid-pro-quo lobbying of the Grossman-Helpman model. It has been well documented, for example in Parker and Parker (1998) that congresspersons and lobbies interact continually on agricultural issues. Congresspersons have full knowledge about their constituents' preference, which is why they seek out memberships on agriculture committees. 
There is little, if any, new information that congresspersons seek from lobbies in order to raise their re-election chances. And there is little, if any, new information that agriculture lobbies possess. At least in the agriculture case, then, we do not see a role for informational lobbying. Our experiment is different from Hansen's (1991), who does find an important role for informational lobbying. He considers a longer period in history during which there were points in time when Congress sought new information from lobbies. At those threshold points, informational lobbying may have led to marked shifts in how Congress began to view agricultural policy. However, on a continuing basis over the 1991-2000 period we see little role for new information.

In the empirical section a reduced form approach is used to explore the association between lobbying spending and agricultural protection. This is the first evidence on such an association in the case of agriculture, and the nature of the exercise and the evidence is exploratory. The main message is evidence of a strong association. Whether the association is via informational channels or whether lobbying is payment for services are questions that are not directly addressed, for they require more theory-based investigation. Gawande and Hoekman (2004) undertake one such examination of the quid pro quo hypotheses. Perhaps, other second generation studies will use more formal structural models to investigate the relative importance of informational versus quid pro quo lobbying in the context of US agricultural policy.

\section{Econometric Evidence}

A. Data

Econometric evidence on the association between lobbying spending and protection in agriculture is presented in this section, using panel data for 44 commodities across 1985-2001. The USDA's Production, Supply and Distribution database PSD Online (at http://www.fas.usda.gov/psd/complete_files/default.asp) was the source for trade and production data in order to construct the import penetration ratio. Time series data over 19852001 for farm products at the 4- and 5-digit Harmonized System (HS) level are available at 
the site. ${ }^{18}$ There is considerable time-series variation as well as cross-sectional variation in the data.

Lobbying data were constructed as described in Section 3 from FEC databases for each election cycle between 1991 and $2000 .{ }^{19}$ Goods are ordered by the of PAC spending-toproduction ratio. ${ }^{20}$ Agricultural protection is primarily measured as nontariff measure coverage ratios, or NTMs. ${ }^{21}$ Data on the incidence of nontariff measures are from the UNCTAD TRAINS database for the years 1993, 1996, and 1999. ${ }^{22}$ There are over 150 types of NTMs documented by UNCTAD, and the measure used here is simply the coverage ratio of the union of all NTMs. This measure, though it aggregates price-type, quantity-type, and investigations-type of NTMs, each with different price-effects, has nevertheless been used in prominent studies of the political economy of trade protection (Trefler, 1993; Gawande and Bandyopadhyay 2000; Goldberg and Maggi, 1999). The TRAINS database also allow narrower NTM classifications such as Price NTMs (P) and threat NTMs (THR),

18 The USDA system is not originally kept at the HS level. The coding into HS was done manually from verbal description. They fit HS 4- or 5-digits descriptions almost perfectly.

${ }^{19}$ Numerous checks have been applied to the lobbying data constructed for this paper. For example, the data are in close proximity to the numbers reported in Opensecrets (2002). A detailed data appendix that describes steps in the construction of the PAC data is available from the author.

${ }^{20}$ Production value is not immediately available, since the PSD database keeps data in quantities, not values, and units of measurement are disparate across goods. But imports can be recovered by dividing the import-to-output ratio by imports (from UNCTAD, see below) in order to recover value of production. Where imports are zero this method does not allow measurement of production, and those observations have to be dropped. Fortunately, imports are strictly zero for only few goods.

21 Agricultural protection may be measured using ad valorem tariffs as well. Model (3) was also estimated using four tariffs measures are available. Three measures are from the UNCTAD TRAINS database at the 6-digit HS levels for 1993, 1996, and 1999. They are an ad valorem measure, a specific tariff measure, and a tariff coverage measure. The fourth measure is an ad valorem tariff measure from the International Trade Commission (ITC) database at the 8-digit HS level for 19972001. Import-weighted averages of these tariffs were used to concord to the 4- and 5-digit HS level of the PSD goods at which the analysis is conducted. While specific tariffs are well explained by the model and reported in the tables, the ad valorem tariff data are not well explained by the variables included. This is probably because tariffs have been determined multilaterally and are not appropriate for testing models of unilateral protection. The tariff results are available from the author.

${ }^{22}$ From the raw data on the UNCTAD TRAINS database, Haveman has constructed binary indicators of NTMs at the 6 digit HS level. These are used in the present analysis. The TRAINS database does have some unresolved issues, some of which are corrected in more recent versions, but recent versions have only recent-dated NTM data. 
countervailing duties (CVD), quality monitoring (QUAL) and specific tariffs (SPECT). Separate analyses of these NTMs are undertaken and reported.

Hoekman, Ng and Olarreaga (2003) have compiled data on the ad valorem equivalent of ad valorem and specific tariffs applied by the US on agricultural imports from the European Union on a set of agricultural commodities that also enjoy export subsidies in the US. Whether these measures of protection are also associated with lobbying spending is also empirically investigated.

Since NTM data are at the HS 6-digit level, they are readily merged with the trade and production data. The sample includes commodities that accounted for about $30 \%$ of total agricultural imports and 45\% of total agricultural output in 1998.

\section{B. Results}

Table 2 presents OLS estimates from a simple linear model with three explanatory variables, plus a constant term. They are (i) the import-output ratio (M/Y), (ii) the export-output ratio (X/Y), and (iii) a measure of lobbying. Two measures of lobbying, termed \%PACEXP and RANKPACEXP, were constructed for each cross-sectional sample. \%PACEXP is PAC spending as a fraction of total PAC spending in the sample under consideration.

RANKPACEXP is the rank of PAC spending (a high rank implies high PAC spending) scaled by sample size $N$. So RANKPACEXP varies between $1 / N$ and 1 , and monotonically increases with PAC spending. RANKPACEXP is less influenced by large values of PAC spending than \%PACEXP, and so their estimated coefficients indicate robustness to these lobbying measures. Six regression models are estimated here, two each for 1993, 1996 and 1999. For the year 1993, the two models have $\mathrm{M} / \mathrm{Y}$ and $\mathrm{X} / \mathrm{Y}$ in common, but include either \%PACEXP or RANKPACEXP. The idea behind estimating the simple model is basically to discover whether lobby matters to non-tariff barrier protection of agriculture. 
Table 2: Agricultural Trade Protection Regressions - NTM I

\begin{tabular}{|c|c|c|c|c|c|c|c|c|c|}
\hline Year Dep. Var & & Constant & $\mathbf{M} / \mathbf{Y}$ & $\mathbf{X} / \mathbf{Y}$ & \%РАCЕXР & RANKPACEXP & $N$ & $R^{2}$ & Adj. $R^{2}$ \\
\hline \multirow[t]{2}{*}{1993 NTM } & est & 0.212 & 0.009 & -0.270 & 2.694 & & 31 & 0.267 & 0.185 \\
\hline & $t$ & 1.981 & 0.599 & -0.724 & $\underline{\underline{2.782}}$ & & & & \\
\hline \multirow[t]{2}{*}{1993 NTM } & est & -0.084 & 0.013 & -0.344 & & 0.754 & 31 & 0.312 & 0.236 \\
\hline & $t$ & -0.518 & 0.932 & -0.961 & & $\underline{\underline{3.167}}$ & & & \\
\hline \multirow[t]{2}{*}{ 1996 NTM } & est & 0.953 & 0.024 & -0.445 & 0.425 & & 33 & 0.292 & 0.219 \\
\hline & $t$ & $\underline{\underline{12.226}}$ & 1.613 & -2.034 & 0.515 & & & & \\
\hline \multirow[t]{2}{*}{ 1996 NTM } & est & 0.756 & 0.026 & -0.468 & & 0.408 & 33 & 0.391 & 0.328 \\
\hline & $t$ & $\underline{6.538}$ & 1.914 & -2.329 & & $\underline{\underline{2.239}}$ & & & \\
\hline \multirow[t]{2}{*}{ 1999 NTM } & est & 0.884 & 0.008 & -0.265 & 0.644 & & 38 & 0.161 & 0.087 \\
\hline & $t$ & $\underline{\underline{9.436}}$ & 0.395 & -0.620 & 0.463 & & & & \\
\hline \multirow[t]{2}{*}{ 1999 NTM } & est & $\overline{0.848}$ & 0.010 & -0.303 & & 0.114 & 38 & 0.164 & 0.090 \\
\hline & $t$ & 6.443 & 0.498 & -0.725 & & 0.568 & & & \\
\hline \multirow[t]{2}{*}{1993 PRICE } & est & 0.092 & -0.001 & 0.006 & 2.264 & & 31 & 0.206 & 0.118 \\
\hline & $t$ & 0.936 & -0.089 & 0.018 & $\underline{\underline{2.553}}$ & & & & \\
\hline \multirow[t]{2}{*}{1993 PRICE } & est & -0.130 & 0.003 & -0.063 & & 0.586 & 31 & 0.214 & 0.126 \\
\hline & $t$ & -0.852 & 0.193 & -0.186 & & $\underline{\underline{2.615}}$ & & & \\
\hline \multirow[t]{2}{*}{ 1996PRICE } & est & 0.000 & 0.000 & 0.000 & 0.018 & & 33 & 0.845 & 0.829 \\
\hline & $t$ & -2.327 & 0.048 & 0.018 & $\underline{12.444}$ & & & & \\
\hline \multirow[t]{2}{*}{ 1996 PRICE } & est & 0.000 & 0.000 & -0.001 & & 0.001 & 33 & 0.107 & 0.014 \\
\hline & $t$ & -0.671 & 0.773 & -0.770 & & 1.695 & & & \\
\hline \multirow[t]{2}{*}{1999 PRICE } & est & 0.000 & 0.000 & 0.000 & 0.023 & & 38 & 0.611 & 0.577 \\
\hline & $t$ & -1.903 & 0.044 & -0.004 & $\underline{7.169}$ & & & & \\
\hline \multirow[t]{2}{*}{ 1999 PRICE } & est & 0.000 & 0.000 & -0.001 & & 0.001 & 38 & 0.100 & 0.021 \\
\hline & $t$ & -0.502 & 0.939 & -0.936 & & 1.698 & & & \\
\hline \multirow[t]{2}{*}{1993 THREAT } & est & 0.015 & 0.004 & -0.093 & 1.989 & & 31 & 0.397 & 0.330 \\
\hline & $t$ & 0.276 & 0.466 & -0.487 & $\underline{4.012}$ & & & & \\
\hline \multirow[t]{2}{*}{1993 THREAT } & est & -0.019 & 0.008 & -0.197 & & 0.226 & 31 & 0.109 & 0.010 \\
\hline & $t$ & -0.183 & 0.848 & -0.858 & & 1.478 & & & \\
\hline \multirow[t]{2}{*}{1996 THREAT } & est & 0.993 & 0.023 & -0.446 & -1.872 & & 33 & 0.312 & 0.241 \\
\hline & $t$ & $\underline{\underline{12.014}}$ & 1.510 & -1.921 & -2.138 & & & & \\
\hline \multirow[t]{2}{*}{1996 THREAT } & est & $\overline{0.801}$ & 0.020 & -0.379 & & 0.229 & 33 & 0.232 & 0.152 \\
\hline & $t$ & $\underline{\underline{5.732}}$ & 1.214 & -1.559 & & 1.040 & & & \\
\hline \multirow[t]{2}{*}{1999 THREAT } & est & $\overline{0.938}$ & 0.008 & -0.264 & -2.335 & & 38 & 0.182 & 0.110 \\
\hline & $t$ & 9.527 & 0.363 & -0.589 & -1.599 & & & & \\
\hline \multirow[t]{2}{*}{1999 THREAT } & est & $\overline{0.878}$ & 0.001 & -0.125 & & -0.041 & 38 & 0.121 & 0.044 \\
\hline & $t$ & $\underline{6.121}$ & 0.064 & -0.274 & & -0.188 & & & \\
\hline
\end{tabular}

Notes:

1. OLS estimates. Sample is cross-section of 5-digit HS agricultural products for 93, 96, 99. NTM data (from TRAINS database) available for those years.

2. NTM=Coverage of imports with some Price-type (PRICE), Quant-type or Threat NTM (THREAT).

3. Bold and underline implies that corresponding estimate is statistical significance at $5 \%$, bold implies that corresponding estimate is statistical significance at $10 \%$.

4. \%PACEXP=PAC spending as a fraction of total PAC spending for the cross-section.

RANKPACEXP=Ranking by PAC spending (high rank implies relatively high PAC spending) scaled by sample size ( $N$ is the highest rank). So $1 \geq$ RANKPACEXP $\geq 0$ and monotonically increases with PAC spending. 
The model estimates in the top panel of Table 2 clearly indicate that lobbying significantly influences the overall NTM coverage ratio. The bottom two panels of Table 2 indicate that price NTMs (PRICE), which comprises a substantial part of the overall NTM coverage, might be driving the NTM results. Threat NTMs (THREAT) produce conflicting results about the influence of lobbying.

The quantitative implications of the estimates are considerable. They indicate a sizable association of lobbying and the nontariff barrier measures. Consider the 1993 NTM model with \%PACEXP. The coefficient of 2.694 shows that for every percentage point increase in \%PACEXP, the NTM coverage ratio is associated with an increase of 0.027 . This is both an economically and statistically significant result. The estimated coefficient of 0.754 on RANKPACEXP in the second NTM model shows that the 1993 results are robust to the two lobbying measures. The 1996 and 1999 NTM results are not as robust. Whereas the coefficients in 1996 indicate an association between lobbying and NTMs, the other coefficients are not statistically significant.

Quite surprisingly, the coefficients on $\mathrm{M} / \mathrm{Y}$ and $\mathrm{X} / \mathrm{Y}$ are not statistically significant in most NTM models for the 3 years. The exceptions are in 1996, where an increase in the export-output ratio is associated with a lower NTM, as one would intuitively expect in industries with intra-industry trade driven by intermediates goods trade. The import-output ratio is borderline statistically significant for the 1996 models, but not in the NTM models for other years.

The second panel on Table 2 displays estimates from the price NTM models for the 3 years. The association of lobbying spending with PRICE (e.g. antidumping duties, countervailing duties and other price-oriented NTMs) is significant. However, the coefficients fluctuate considerably across the 3 years. For example, \%PACEXP has a coefficient of 2.264 for 1993, but it drops to 0.018 and 0.023 in 1996 and 1999, respectively. However, the coefficients retain their statistical significance. That points to the possibility that one or two large values of \%PACEXP are determining the regression (which also explains why the fit for those years is abnormally good). Even though RANKPACEXP is is less susceptible to influential data points, it produces the same inference, that lobbying is strongly associated with the imposition of price NTMs. The drop in the estimates from 1993 is also indicative of the fact that price NTMs dropped over this period according to the 
Uruguay Round. The third panel in Table 2 reports estimates from threat NTM models for the 3 years. Whereas in 1993 lobbying was associated with THREAT, there was no association in the other years. Apparently, THREAT was lowered considerably after the inception of the Uruguay Round.

CVD and QUAL, however, did not reduce in frequency and intensity after the inception of the Uruguay Round. This message is evident from the results in Table 3. The top panel of Table 3 indicates that \%PACEXP is strongly associated with the imposition of CVDs in all the three years. However, the coefficient on RANKPACEXP is statistically insignificant indicating the possibility of influential \%PACEXP values. The bottom panel of Table 3 indicates that QUAL is significantly associated with lobbying spending and is robust across the two measures of lobbying. The size of the coefficients on \%PACEXP and RANKPACEXP also indicate that QUAL does not appear to have declined after the Uruaguay Round.

Table 3: Agricultural Trade Protection Regressions - NTM II

\begin{tabular}{|c|c|c|c|c|c|c|c|c|c|}
\hline Year Dep. Var. & & Constant & $\mathbf{M} / \mathbf{Y}$ & $\mathbf{X} / \mathbf{Y}$ & \%PACEXP & RANKPACEXP & $N$ & $R^{2}$ & Adj. $R^{2}$ \\
\hline \multirow[t]{2}{*}{19993 CVD } & est & -0.038 & -0.007 & 0.191 & 1.997 & & 31 & 0.378 & 0.309 \\
\hline & $t$ & -0.691 & -0.987 & 0.997 & $\underline{\underline{4.026}}$ & & & & \\
\hline \multirow[t]{2}{*}{1993 CVD } & est & -0.048 & -0.003 & 0.080 & & 0.183 & 31 & 0.054 & -0.052 \\
\hline & $t$ & -0.451 & -0.341 & 0.341 & & 1.180 & & & \\
\hline \multirow[t]{2}{*}{1996 CVD } & est & -0.028 & -0.008 & 0.117 & 2.155 & & 33 & 0.395 & 0.333 \\
\hline & $t$ & -0.605 & -0.881 & 0.885 & $\underline{4.331}$ & & & & \\
\hline \multirow[t]{2}{*}{$1996 \mathrm{CVD}$} & est & -0.050 & -0.002 & 0.031 & & 0.201 & 33 & 0.064 & -0.033 \\
\hline & $t$ & -0.530 & -0.200 & 0.193 & & 1.360 & & & \\
\hline \multirow[t]{2}{*}{1999 CVD } & est & -0.064 & -0.015 & 0.320 & 2.778 & & 38 & 0.288 & 0.225 \\
\hline & $t$ & -1.248 & -1.352 & 1.362 & $\underline{\underline{3.634}}$ & & & & \\
\hline \multirow[t]{2}{*}{1999 CVD } & est & -0.040 & -0.007 & 0.154 & & 0.140 & 38 & 0.045 & -0.039 \\
\hline & $t$ & -0.481 & -0.582 & 0.577 & & 1.096 & & & \\
\hline \multirow[t]{2}{*}{1993 QUAL } & est & 0.064 & 0.008 & -0.225 & 2.728 & & 31 & 0.514 & 0.460 \\
\hline & $t$ & 1.049 & 0.992 & -1.054 & $\underline{\underline{4.930}}$ & & & & \\
\hline \multirow{2}{*}{1993 QUAL } & est & -0.004 & 0.014 & -0.362 & & 0.348 & 31 & 0.187 & 0.096 \\
\hline & $t$ & -0.033 & 1.296 & -1.326 & & 1.917 & & & \\
\hline \multirow[t]{2}{*}{1996 QUAL } & est & -0.006 & 0.000 & -0.004 & 3.231 & & 33 & 0.599 & 0.558 \\
\hline & $t$ & -0.123 & 0.018 & -0.029 & $\underline{\underline{6.490}}$ & & & & \\
\hline \multirow[t]{2}{*}{1996 QUAL } & est & -0.136 & 0.009 & -0.135 & & 0.489 & 33 & 0.252 & 0.175 \\
\hline & $t$ & -1.321 & 0.761 & -0.756 & & $\underline{3.020}$ & & & \\
\hline \multirow[t]{2}{*}{1999 QUAL } & est & -0.022 & -0.006 & 0.122 & 4.294 & & 38 & 0.340 & 0.282 \\
\hline & $t$ & -0.318 & -0.386 & 0.383 & $\underline{\underline{4.141}}$ & & & & \\
\hline \multirow[t]{2}{*}{1999 QUAL } & est & -0.132 & 0.006 & -0.135 & & 0.498 & 38 & 0.222 & 0.153 \\
\hline & $t$ & -1.233 & 0.400 & -0.397 & & $\underline{\underline{3.062}}$ & & & \\
\hline
\end{tabular}

Notes: 1. See note to Table 2. 2 . $\mathrm{CVD}=$ Countervailing Duties, $\mathrm{QUAL}=$ Quality Monitoring. 
Table 4: Agricultural Trade Protection Regressions - Specific Tariffs

\begin{tabular}{|c|c|c|c|c|c|c|c|c|c|}
\hline \multicolumn{2}{|c|}{ Year Dep. Var. } & Constant & $\mathbf{M} / \mathbf{Y}$ & $\mathbf{X} / \mathbf{Y}$ & \%РACEXP & RANKPACEXP & \multicolumn{3}{|c|}{$N \quad R^{2} \quad$ Adj. $R^{2}$} \\
\hline 1993 SPECT & est & 0.232 & -0.046 & 1.281 & 1.488 & & 31 & 0.311 & 0.234 \\
\hline & $t$ & $\underline{\underline{2.058}}$ & -2.978 & $\underline{3.258}$ & 1.460 & & & & \\
\hline 1993 SPECT & est & $\overline{0.049}$ & -0.044 & $\overline{1.246}$ & & 0.450 & 31 & 0.334 & 0.260 \\
\hline & $t$ & 0.285 & -2.913 & $\underline{3.259}$ & & 1.769 & & & \\
\hline 1996 SPECT & est & 0.261 & $\overline{-0.006}$ & $\overline{0.144}$ & 2.564 & & 33 & 0.218 & 0.137 \\
\hline & $t$ & $\underline{\underline{2.820}}$ & -0.354 & 0.553 & $\underline{\underline{2.621}}$ & & & & \\
\hline 1996 SPECT & est & 0.064 & 0.001 & 0.036 & & 0.567 & 33 & 0.192 & 0.109 \\
\hline & $t$ & 0.428 & 0.085 & 0.140 & & $\underline{\underline{2.393}}$ & & & \\
\hline 1999SPECT & est & 0.242 & -0.015 & 0.387 & 3.227 & & 38 & 0.136 & 0.060 \\
\hline & $t$ & $\underline{\underline{2.248}}$ & -0.669 & 0.789 & $\underline{2.021}$ & & & & \\
\hline 1999SPECT & est & 0.083 & -0.006 & 0.194 & & 0.521 & 38 & 0.162 & 0.088 \\
\hline & $t$ & 0.557 & -0.271 & 0.409 & & $\underline{\underline{2.298}}$ & & & \\
\hline
\end{tabular}

Notes: 1. See note to Table 2.

2. SPECT $=$ Specific Tariff.

Similar inferences may be drawn about specific tariffs (SPECT) from the estimates reported in Table 4. The association of SPECT with lobbying spending is found for both \%PACEXP and RANKPACEXP (except in 1993 when the coefficient on \%PACEXP is borderline significant). Curiously, in the 1993 models of SPECT, M/Y and X/Y have signs that are contrary to expectation. For example, $\mathrm{X} / \mathrm{Y}$ has a positive coefficient, implying that the higher is the export-output ratio, the higher is the specific tariff on that product. It is likely that tariffs are protecting imports of similar products and thus promoting exports of those products. This is an instance of tariffs as export promotion, an idea that was set forth in Krugman (1984).

Table 5 uses data on agriculture tariffs on imports from the European Union for those goods that also benefited export subsidies in the US. These data are from Hoekman, Ng, and Olarreaga (2002). ${ }^{23}$ Specifically, Table 5 models the average US tariff (during 1995-1998) on products that also benefited from a US export subsidy. The extra variable that appears in these models is the corresponding European Union average tariff (AVGEU15). That variable is included in order to examine whether US tariffs retaliate against EU tariffs for these goods. The clearest inference from Table 5 is that lobbying spending, whether measured by \%PACEXP or RANKPACEXP, is powerfully associated with the imposition of US tariffs on products whose exports are subsidized in the US. This finding is robust for each of the four

\footnotetext{
${ }^{23}$ I am grateful to Francis $\mathrm{Ng}$ for providing the data and its documentation.
} 
years 1995-98. Table 6 estimates the same set of models, but the dependent variable now is the maximum US tariff (over 1995-1998) for each of these products in the sample (e.g. 24 industries in 1995). The estimates from the models affirm the earlier findings, implying that the results are robust to whether we model the average US tariff or the maximum US tariff on these products.

Table 5: Determinants of agricultural tariffs (incl. Specific Tariffs) on products with export subsidies

Dependent Variable: Average Tariff between 1995 and 1998

\begin{tabular}{|c|c|c|c|c|c|c|c|c|c|c|c|}
\hline \multirow[b]{2}{*}{ year } & \multirow[b]{2}{*}{ Dep. Var. } & & \multirow[b]{2}{*}{ constant } & \multirow[b]{2}{*}{$\mathbf{M} / \mathbf{Y}$} & \multirow[b]{2}{*}{$\mathbf{X} / \mathbf{Y}$} & \multicolumn{4}{|c|}{ \%PAC RANKPA } & \multirow[b]{2}{*}{$R^{2}$} & \multirow[b]{2}{*}{ Adj. $R^{2}$} \\
\hline & & & & & & AvgEU15 & EXP & CEXP & $N$ & & \\
\hline \multirow[t]{2}{*}{1995} & AvgUS & est & 0.008 & -0.009 & 0.088 & 0.114 & 0.905 & & 24 & 0.513 & 0.410 \\
\hline & & $t$ & 0.279 & 1.166 & 1.144 & 0.366 & 4.091 & & & & \\
\hline \multirow[t]{2}{*}{1995} & AvgUS & est & -0.025 & -0.005 & 0.056 & -0.323 & & 0.187 & 24 & 0.321 & 0.178 \\
\hline & & $t$ & 0.541 & 0.620 & 0.609 & 0.889 & & $\underline{\underline{2.574}}$ & & & \\
\hline \multirow[t]{2}{*}{1996} & AvgUS & est & 0.052 & -0.005 & 0.062 & -0.443 & 1.067 & & 26 & 0.416 & 0.304 \\
\hline & & $t$ & $\underline{\underline{2.126}}$ & 0.914 & 0.837 & $\underline{\underline{2.486}}$ & $\underline{\underline{3.667}}$ & & & & \\
\hline \multirow[t]{2}{*}{1996} & AvgUS & est & -0.047 & -0.005 & 0.076 & -0.193 & & 0.226 & 26 & 0.375 & 0.256 \\
\hline & & $t$ & 1.137 & 0.990 & 0.989 & 1.273 & & $\underline{\underline{3.349}}$ & & & \\
\hline \multirow[t]{2}{*}{1997} & AvgUS & est & 0.045 & -0.005 & 0.074 & -0.373 & 1.094 & & 28 & 0.314 & 0.194 \\
\hline & & $t$ & 1.760 & 0.933 & 0.875 & $\underline{\underline{2.026}}$ & $\underline{\underline{3.082}}$ & & & & \\
\hline \multirow[t]{2}{*}{1997} & AvgUS & est & -0.038 & -0.006 & 0.105 & -0.158 & & 0.195 & 28 & 0.275 & 0.149 \\
\hline & & $t$ & 0.859 & 1.188 & 1.182 & 0.998 & & $\underline{\underline{2.788}}$ & & & \\
\hline \multirow[t]{2}{*}{1998} & AvgUS & est & 0.030 & -0.011 & 0.201 & -0.394 & 1.104 & & 30 & 0.370 & 0.270 \\
\hline & & $t$ & 1.240 & 1.692 & 1.650 & $\underline{\underline{2.312}}$ & $\underline{\underline{3.234}}$ & & & & \\
\hline \multirow[t]{2}{*}{1998} & AvgUS & est & -0.044 & -0.011 & 0.210 & -0.169 & & 0.182 & 30 & 0.337 & 0.231 \\
\hline & & $t$ & 1.147 & 1.682 & 1.683 & 1.153 & & $\underline{\underline{2.949}}$ & & & \\
\hline
\end{tabular}

Interestingly, the 1996, 1997, and 1998 tariff appear to be deterred by EU tariffs on these particular products. The coefficient on Table 5 on AVGEU15 is -0.443 for the year 1996 in the model with \%PACEXP included. That indicates that a higher EU average tariff deterred the average US tariff. While this is a somewhat surprising finding, it is not robust across the two models for each year. With RANKPACEXP included, the coefficient on AVGEU15 becomes statistically insignificant. It is quite possible that the most influential \%PACEXP values are correlated with influential AVGEU15 values. When influential values get lesser weight (as happens when RANKPACEXP is included), the correlation between the lobbying variable and AVGEU15 declines, and we get statistically insignificant results on 
AVGEU15. In sum, the coefficient on retaliation or deterrents is not robust across the years and across the models estimated. This also holds true in Table 6 for the maximum US tariff.

\section{Table 6: Determinants of agricultural tariffs (incl. Specific tariffs) on products with export subsidies}

Dependent Variable: Maximum Tariff between 1995 and 1998

\begin{tabular}{|c|c|c|c|c|c|c|c|c|c|c|c|}
\hline \multirow[b]{2}{*}{ year } & \multirow[b]{2}{*}{ Dep. Var. } & & & \multicolumn{8}{|c|}{ \%PAC RANKP } \\
\hline & & & constant & $\mathbf{M} / \mathbf{Y}$ & $\mathbf{X} / \mathbf{Y}$ & AvgEU15 & EXP & & $N$ & $R^{2}$ & Adj. $R^{2}$ \\
\hline \multirow[t]{2}{*}{1995} & MaxRateUS & est & 0.022 & -0.010 & 0.101 & -0.002 & 1.358 & & 24 & 0.537 & 0.439 \\
\hline & & 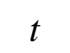 & 0.5 & 0.960 & 0.934 & 0. & $\underline{4.256}$ & & & & \\
\hline \multirow[t]{2}{*}{1995} & MaxRateUS & est & -0.036 & -0.008 & 0.077 & -0.5 & & & 24 & 382 & 0.252 \\
\hline & & 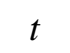 & 0.5 & 0.629 & 0.611 & 1. & & & & & \\
\hline \multirow[t]{2}{*}{1996} & MaxRateUS & est & 0.07 & -0.006 & 0.084 & -0.5 & 1.785 & & 26 & 0.464 & 0.362 \\
\hline & & $t$ & $\underline{2.2}$ & 0.878 & 0.796 & $\underline{3.1}$ & $\underline{4.089}$ & & & & \\
\hline \multirow[t]{2}{*}{1996} & MaxRateUS & est & -0.083 & -0.006 & 0.098 & -0. & & 0.3 & 26 & 0.428 & 0.319 \\
\hline & & 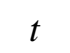 & 1.3 & 0.887 & 0.8 & 1.8 & & $\underline{3.7}$ & & & \\
\hline \multirow[t]{2}{*}{1997} & MaxR & est & 0.06 & -0.007 & 0.112 & -0.4 & 1.832 & & 28 & .339 & 0.224 \\
\hline & & $t$ & & 0.934 & 0.872 & $\underline{2.5}$ & $\underline{3.272}$ & & & & \\
\hline \multirow[t]{2}{*}{1997} & MaxR & est & -0 & -0.010 & & -0 . & & & 28 & 0.329 & 0.212 \\
\hline & & 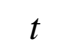 & $1 .($ & 1.1 & 1.1 & & & & & & \\
\hline \multirow[t]{2}{*}{1998} & MaxRateUS & est & 0.044 & -0.017 & 0.315 & -0.468 & 1.860 & & 30 & 0.399 & 0.303 \\
\hline & & 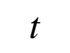 & & 1.775 & 1.731 & $\underline{2.9}$ & $\underline{3.527}$ & & & & \\
\hline \multirow[t]{2}{*}{1998} & MaxRateUS & est & -0.077 & -0.016 & 0.3 & -0.2 & & 0.3 & 30 & 0.374 & 0.274 \\
\hline & & $t$ & 1.345 & 1.648 & 1.652 & 1.717 & & 33 & & & \\
\hline
\end{tabular}

Notes:

Data Source: Hoekman, Ng, and Olarreaga (2004)

In sum, the econometric estimates point to two fairly strong associations from US data from the 1990s across agricultural products, and a fairly surprising non-association. The first strong association is that between lobbying spending by agricultural PACs and measures of nontariff barriers. This association is seen to be robust across aggregate NTMs as well NTMs disaggregated by type. While there is no evidence of such an association with ad valorem tariffs, probably because they have been multilaterally lowered, lobbying is still associated with specific tariffs. The second strong association is that between the average US tariff (taken over the 1995-98 period) on those goods that also enjoy an export subsidy in the US and lobbying spending. The surprising non-association is between the agricultural protection, however it is defined, and trade measures such as import penetration and export-to-output ratio. If anything, the surprise is that it is not these variables, often the key issue variables in 
empirical investigations of the political economy of protection, but rather direct measures of pressure like lobbying spending, that are strongly associated with agricultural protection.

While the econometric model used here is not in itself the appropriate vehicle to determine whether lobbying is payment for services or whether it influences protection through the channels of information provision by the lobbyist, the analysis of the data together with the survey of the literature suggests that lobbying in agriculture might be payment for services more than purely informational lobbying. However, more theory based estimation is required before such a claim can be made conclusively.

\section{Conclusion}

The paper has analyzed the structure of lobbying by agricultural PACs over the 1991-2000 period. A detailed graphical analysis of campaign contributions by agricultural PACs indicates that (i) while many PACs exist, in most sectors the majority of contributions are made by very few PACs, that is, giving by PACs is highly concentrated, (ii) PAC contributions seem to be made with a view to gain access to politicians, but PACs respond by contributing more when such contributions might influence election outcomes, (iii) the top 20 recipients among House candidates often consist of members of the Agriculture committee, (iv) the top 20 recipients among Senate candidates have fewer members of committees that are connected to agricultural policy, (v) the top House recipients of agricultural PAC money receive a significant portion of their total PAC receipts from agricultural PACs, which is probably a reason why they vie for positions on the Agriculture committee, (vi) the top Senate and House candidate receive about equal amounts from agricultural PACs. In sum, PACs seem to be quite effective in influencing agriculture policy in the U.S.

A reduced-form econometric model of agricultural protection provides clear evidence of a strong association of lobbying with protection. That evidence together with the graphical analysis, appears to demonstrate that PAC money wields a strong influence over agricultural protection. Whether it is PAC money that is influential or whether PAC money primarily allows access to politicians so that PACs can then influence policy by supplying (costly) information that politicians find valuable in enhancing their future election chances, remains an open question worthy of further study. It is hoped that this study encourages more structural econometric evidence on the relative validity of the two channels of influence. 


\section{References}

Ainsworth, Scott and Itai Sened. 1993. "The Role of Lobbyists: Entrepreneurs with Two Audiences" American Journal of Political Science 37: 834-866.

Anderson, Kym. 1992. "International Dimensions of the Political Economy of Distortionary Price and Trade Policies." Open Economies: Structural Adjustment and Agriculture. (1992): 290-310. Cambridge: Cambridge University Press.

Anderson, Kym and Yujiro Hayami. 1986. The Political Economy of Agricultural Protection. Sydney: Allen and Unwin.

Anderson, Kym. 1994. "Trade Negotiations and Farm Policy." Economic Policy: A European Forum 9: 12-52.

Austen-Smith, David. 1995. "Campaign Contributions and Access.” American Political Science Review 89: 566-581.

Austen-Smith, David. 1993. "Information and Influence: Lobbying for Agendas and Votes" American Journal of Political Science 37: 799-833.

Barkley, Andrew P. 1996. "Are Politicians Addicted to Agricultural Protection? A Dynamic Model of Political Economy." in Papers in Honor of D. Gale Johnson, volume 2: 263-82. Chicago: University of Chicago Press.

Bernheim B. Douglas and Michael Whinston. 1986. "Menu Auctions, Resource Allocation, and Economic Influence”. Quarterly Journal of Economics 101:1-31.

Bauer, Raymond, Ithiel de Sola Pool, and Lewis Dexter. 1963. American Business and Public Policy. New York: Atherton.

Beaulieu, Eugene, and Chris Magee. 2002. "Campaign Contributions and Trade Policy: New Tests of Stolper-Samuelson". Manuscript.

Becker, Gary S. 1983. "A Theory of Competition among Pressure Groups for Political Influence.” Quarterly Journal of Economics 98: 371-400.

Bennedsen, Morten, and Sven E. Feldman. 2002. "Lobbying Legislatures". Journal of Political Economy 110: 919-948.

Brooks, Jonathan C., A. Colin Cameron, and Colin A. Carter. 1998. "Political Action Committee Contributions and U.S. Congressional Voting on Sugar Legislation." American Journal of Agricultural Economics 80: 441-454.

Bullock, David S. 1994. "In Search of Rational Government: What Political Preference Function Studies Measure and Assume." American Journal of Agricultural Economics 76: 347-361

Carter, Colin A. and W. H. Gardiner eds. 1988. Elasticities in International Agricultural Trade. Boulder, CO: Westview Press.

Congressional Quarterly. Politics in America. Washington, DC: CQ Press. Various Issues from 1991-1999.

Crandall, Robert W. 1978. "Federal Government Initiatives to Reduce the Price Level". Brookings Papers on Economic Activity 2.

de Gorter, H and Johan F. M. Swinnen. 2002. "Political Economy of Agricultural Policies." In B. L. Gardner and G. C. Rausser (eds.) Handbook of Agricultural Economics. New York: Elsevier. 
de Gorter, H. and Johan F. M. Swinnen. 1994. "The Economic Polity of Farm Policy." Journal of Agricultural Economics 45: 312-326.

de Gorter, H. and Y. Tsur. 1991. "Explaining Price Policy Bias in Agriculture." American Journal of Agricultural Economics 73: 1244-1254.

Dijkstra, Bouwe. 2002. Lecture notes on Choice of Instruments.

Downs, Anthony. 1957. An Economic Theory of Democracy. New York: Harper.

Fenno, Richard E. 1973. Congressmen in Committees. Boston: Little, Brown.

Gardner, Bruce L. 1996. "The Political Economy of U.S. Export Subsidies for Wheat." In Anne. O. Krueger (ed.) The Political Economy of American Trade Policy (1996): 291331. Chicago: University of Chicago Press.

Gardner, Bruce L. 1987. "Causes of U.S. Farm Commodity Programs." Journal of Political Economy 97: 290-310.

Gawande, Kishore. 2003. "Lobbying and U.S. Agricultural Policy." Bush School of Government, Texas A\&M Working Paper.

Gawande, Kishore and Usree Bandyopadhyay. 2000. "Is Protection for Sale? A Test of the Grossman-Helpman Theory of Endogenous Protection." Review of Economics and Statistics 89:139-152.

Gawande, Kishore and Pravin Krishna. 2002. "The Political Economy of Trade Policy: Empirical Approaches." In J. Harrigan and E. Kwan Choi (eds.) Handbook of International Trade. Oxford and Malden, MA: Blackwell Publishers.

Goldberg, Pinelopi and Giovanni Maggi. 1999. "Protection for Sale: An Empirical Investigation". American Economic Review 89: 1135-1155.

Grossman, Gene and Elhanan Helpman. 1994. "Protection for Sale". American Economic Review 84: 833-850.

Grossman, Gene and Elhanan Helpman. 2002. Interest Groups and Trade Policy. Princeton, NJ: Princeton University Press.

Hansen, John M. 1991. Gaining Access: Congress and the Farm Lobby, 1919-81. Chicago: University of Chicago Press.

Honma, Masayoshi. 1993. “Japan's Agricultural Policy and Protection Growth". In T. Ito and A. O. Krueger (eds.) Trade and Protectionism. Chicago: University of Chicago Press, 95-114.

Hoekman, B., F. Ng and M. Olarreaga. 2004. "Reducing Agricultural Tariffs versus Domestic Support: What is More Important for Developing Countries?," World Bank Economic Review, 18(2), 175-204

Hufbauer, Gary C., Diane T. Berliner and Kimberly A. Elliott. (1986). :Trade Protection in the United States: 31 Case Studies". Washington, DC:Institute of International Economics.

Kollman, Ken.1997. "Inviting Friends to Lobby: Interest Groups, Ideological Bias, and Congressional Committees." American Journal of Political Science 41: 519-544.

Krueger, Anne O. 1996. "The Political Economy of American Trade Policy." Chicago: University of Chicago Press.

Krueger, Anne O. and Schiff, Maurice and Valdes, Alberto. 1991. The Political Economy of Agricultural Pricing Policy Volume 1. Baltimore and London: Johns Hopkins University Press for the World Bank.

Krugman, Paul R. 1984. "Import Protection as Export Promotion: International Competition in the Presence of Oligopoly and Economies of Scale." In H. Kierzkowski (ed.), 
Monopolistic Competition and International Trade. Oxford, UK: Oxford University Press: 180-193.

Magee, Stephen P. 1972. "The Welfare Effects of Restrictions on US Trade". Brookings Papers on Economic Activity 3.

McCalman, Philip. 2002. "Protection for Sale and Trade Liberalization: An Empirical Investigation." Review of International Economics

Milbraith, Lester W. 1960. The Washington Lobbyists. Chicago: Rand-McNally.

Mitra, Devashish, Dimitrios D. Thomakos, and Mehmet A. Ulubasoglu. 2002. Protection for Sale in a Developing Country: Democracy Versus Dictatorship. Review of Economics and Statistics 84: 497-508.

Olper, Alessandro. 1998. "Political Economy Determinants of Agricultural Protection Levels in EU Member States: An Empirical Investigation.” European Review of Agricultural Economics 25: 463-87.

Olson, Mancur. 1965. The Logic of Collective Action. Cambridge, MA: Harvard University Press.

Opensecrets, 2002. http://www.opensecrets.org

Orden, David. 1996. "Agricultural Interest Groups and the North American Free Trade Agreement." In Anne. O. Krueger (ed.) The Political Economy of American Trade Policy: 335-82. Chicago: University of Chicago Press.

Paarlberg, Robert. 1996. "Agricultural Interest Groups and the North American Free Trade Agreement: Comment." In Anne. O. Krueger (ed.) The Political Economy of American Trade Policy (1996): 382-84. Chicago: University of Chicago Press.

Paarlberg, Robert. 1996. "The Political Economy of U.S. Export Subsidies for Wheat: Comment." In Anne. O. Krueger (ed.) The Political Economy of American Trade Policy (1996): 332-34. Chicago London: University of Chicago Press.

Paarlberg, Robert. 1989. "The Political Economy of American Agricultural Policy.” American Journal of Agricultural Economics 71: 1157-1164.

Parker, Glenn R., and Suzanne L. Parker. 1998. "The Economic Organization of Legislatures and How it Affects Congressional Voting." Public Choice 95: 117-129.

Peltzman, Sam. 1976. "Toward a More General Theory of Regulation." Journal of Law and Economics 19:211-240.

Stigler, George J.. 1971. "The Theory of Economic Regulation," Bell Journal of Economics and Management Science 2:3-21.

Swinnen, Johan F. M. 1994. "A Positive Theory of Agricultural Protection.” American Journal of Agricultural Economics 76: 1-14.

Van Bastelaer, Thierry. 1998. "The Political Economy of Food Pricing: An Extended Empirical Test of the Interest Group Approach." Public Choice 96: 43-60.

Van Doren, Terry V., Dana L. Hoag, and Thomas G. Field. 1999. "Political and Economic Factors Affecting Agricultural PAC Contribution Strategies." American Journal of Agricultural Economics 81: 397-407.

Vousden, Neil. 1990. The economics of trade protection. Cambridge, UK: Cambridge University Press.

Weingast, B. R. and W. J. Marshall. 1988. The Industrial Organization of Congress; or Why Legislatures, Like Firms, are Not Organized as Markets. Journal of Political Economy 132-163. 
Wright, John. 1990. "Contributions, Lobbying, and Committee Voting in the U.S. House of Representatives.” American Political Science Review 84: 417-438.

U. S. Bureau of the Census, Census of Agriculture 1997. Website:

U.S. Department of Agriculture, Economic Research Service, 2002: http://www.ers.usda.gov 